\title{
Histone deacetylase inhibitors potentiate TNF-related apoptosis-inducing ligand (TRAIL)-induced apoptosis in lymphoid malignancies
}

\author{
S Inoue ${ }^{1}, M_{\text {MacFarlane }}{ }^{1}$, N Harper $^{1}$, LMC Wheat ${ }^{1}$, MJS Dyer ${ }^{1}$ \\ and GM Cohen*,1 \\ 1 MRC Toxicology Unit, Hodgkin Building, University of Leicester, PO Box 138, \\ Lancaster Road, Leicester LE1 9HN, UK \\ * Corresponding author: GM Cohen, MRC Toxicology Unit, Hodgkin Building, \\ University of Leicester, PO Box 138, Lancaster Road Leicester, LE1 9HN, UK \\ Tel: + 44116 2525601; Fax: + 44116 2525616; E-mail: gmc2@le.ac.uk
}

Received 17.5.04; revised 21.10.04

Edited by G Melino

\begin{abstract}
New therapies are required for chronic lymphocytic leukemia (CLL), an incurable disease characterized by failure of mature lymphocytes to undergo apoptosis. Activation of cell surface death receptors, such as via TRAIL receptor ligation, may provide a novel therapeutic target for various malignancies. However, CLL and other lymphoid malignancies are resistant to TRAIL. We report that low concentrations of histone deacetylase (HDAC) inhibitors, such as depsipeptide, which alone failed to induce apoptosis, markedly sensitize CLL cells and other primary lymphoid malignancies to TRAIL-induced apoptosis. These combinations caused little or no toxicity to normal lymphocytes. HDAC inhibitors sensitized resistant cells to TRAIL-induced apoptosis by facilitating formation of an active death-inducing signalling complex (DISC), leading to the rapid activation of caspase-8. The facilitated DISC formation also occurred in the absence of TRAIL-R2 upregulation. Thus, the combination of HDAC inhibitors and TRAIL may be valuable in the treatment of various hemopoietic malignancies.

Cell Death and Differentiation (2004) 11, S193-S206.

doi:10.1038/sj.cdd.4401535
\end{abstract}

Keywords: chronic lymphocytic leukemia; tumor necrosis factorrelated apoptosis-inducing ligand; histone deacetlyase inhibitors; depsipeptide; DISC

Abbreviations: CLL, chronic lymphocytic leukemia; HDAC, histone deacetylase; DISC, death-inducing signalling complex; TNF, tumor necrosis factor; TRAIL, TNF-related apoptosisinducing ligand; c-FLIP, Flice inhibitory protein

\section{Introduction}

Apoptosis may be induced by two main pathways: triggering of cell surface death receptors (the extrinsic pathway) or by perturbation of mitochondria (the intrinsic pathway), with caspase- 8 and -9 being the apical caspases, respectively. ${ }^{1,2}$ Several members of the tumor necrosis factor (TNF) family, including TNF, CD95/FasL and TNF-related apoptosis-inducing ligand (TRAIL), induce apoptosis by the extrinsic pathway. In CD95 and TRAIL-induced, but not in TNF-induced, apoptosis, the adaptor molecule FADD/MORT $1^{3,4}$ is initially recruited to the death receptor, and this in turn recruits caspase-8 into the death-inducing signalling complex (DISC).$^{5-9}$ TRAIL induces apoptosis in a wide range of tumor cell lines, but not in most normal cells. ${ }^{10-12}$ TRAIL interacts with four distinct membrane-bound receptors: two death receptors, TRAIL-R1 (DR4) and TRAIL-R2 (DR5/TRICK2), and two putative decoy receptors, TRAIL-R3 (TRID/DcR1/ LIT) and TRAIL-R4 (DcR2/TRUNDD) (reviewed in Ashkenazi and Dixit ${ }^{13}$ ). TRAIL- and CD95-induced apoptosis is also regulated by inhibitory molecules, such as Flice inhibitory protein (c-FLIP), which competes with caspase-8 for binding to $F A D D,{ }^{14,15}$ and can therefore interfere with signalling from the DISC by antagonizing caspase- 8 activation. FLIP exists as two differentially spliced isoforms (FLIP $\mathrm{F}_{\mathrm{L}}$ and FLIPS $)$, both of which are recruited to the CD95 DISC and inhibit CD95induced apoptosis. ${ }^{14-16}$

TRAIL may represent a suitable ligand for exploitation of receptor-mediated apoptosis as a novel therapeutic strategy for many forms of cancer, as it does not generally induce cell death in normal tissues in contrast to TNF or CD95. ${ }^{13}$ However, primary cells from patients with chronic lymphocytic leukemia (CLL), and other B-cell malignancies, such as B-cell non-Hodgkin's lymphoma, are commonly resistant to CD95and TRAIL-mediated apoptosis. ${ }^{17-21}$ The mechanism(s) of CD95 and TRAIL resistance in these cells is unclear, but may include lack of expression of functional receptors or overexpression of inhibitory molecules. Recently, we have shown that the resistance of CLL cells to TRAIL-induced apoptosis is upstream of caspase-8 activation and may be partly due to low levels of receptor expression as well as due to low levels of DISC formation with a high ratio of $C-F_{L} P_{L}$ to caspase-8 within the DISC. ${ }^{20}$ Sensitivity to TRAIL in many resistant cell lines is enhanced by combination treatments with either chemotherapeutic agents or irradiation by a variety of proposed mechanisms including an increase in cell surface death receptor expression, a decrease in c-FLIP levels, restoration of caspase-8 expression or inhibition of Akt (reviewed in Ozoren and El-Deiry ${ }^{22}$ and Wajant et al. ${ }^{23}$ ). As almost all of the chemotherapeutic agents used in such combinations are toxic to normal cells, it is important to find nontoxic agents, which synergize with TRAIL. Recently, several inhibitors of histone deacetylase (HDAC), which inhibit tumor growth both in vivo and in vitro at nontoxic doses, have entered clinical trials. ${ }^{24,25}$ The acetylation status of histones alters chromatin structure, thereby modulating gene expression, and is governed by the relative activities of histone acetyltransferases 
and HDACs. Altered histone acetyltransferase or HDAC is associated with several malignancies, including hematological malignancies. ${ }^{24-26}$ HDAC inhibitors exert their antitumor effects due to their ability to induce growth arrest, differentiation and apoptosis. ${ }^{24-26}$ Most studies describing the induction of apoptosis by HDAC inhibitors suggest they induce apoptosis via the intrinsic pathway, although in some cellular contexts other enzymes may be involved, including a proposed activation of the extrinsic pathway in one study in CLL. ${ }^{27-30}$ In addition to inducing apoptosis, there are conflicting reports of the potentiation of death receptorinduced apoptosis by HDAC inhibitors. Proposed mechanisms involve increased expression of death receptors and their ligands or decreases in C-FLIP, c-IAP2 and XIAP. ${ }^{29,31-33}$ Some recent studies have described that co-treatment of HDAC inhibitors with TRAIL induced apoptosis but little or no mechanistic insight was provided. ${ }^{34-36}$ We now demonstrate that nanomolar concentrations of HDAC inhibitors sensitize resistant primary cells from patients with CLL to TRAILinduced apoptosis by facilitating increased formation of the TRAIL DISC. We propose that the combination of HDAC inhibitors and TRAIL agonists could be of therapeutic benefit in CLL as well as other TRAIL-resistant hematological malignancies.

\section{Results}

\section{Synergistic induction of apoptosis in Jurkat and CLL cells treated with HDAC inhibitors and TRAIL}

We examined the effects of two structurally unrelated HDAC inhibitors, Trichostatin A and depsipeptide, on CD95- and TRAIL-induced apoptosis in freshly isolated peripheral blood B cells from patients with CLL and the T-cell precursor acute lymphoblastic leukemia cell line, Jurkat. CLL cells were chosen, as they are resistant to TRAIL and CD95 20,37 and resistant to the apoptosis-inducing properties of depsipeptide, requiring depsipeptide ( $15 \mathrm{nM}$ ) for 4 days to reduce viability by $50 \%{ }^{38}$ In our hands, treatment of either CLL cells for 8 or $16 \mathrm{~h}$ or the Jurkat cell line for $8 \mathrm{~h}$ with nanomolar concentrations of both HDAC inhibitors failed to induce significant apoptosis. In contrast, pretreatment with these concentrations of the HDAC inhibitors, followed by treatment with CD95 or TRAIL, resulted in a marked increase in apoptosis in Jurkat cells, as assessed by an increase in phosphatidylserine (PS) externalization (Figure 1a) and a decrease in the percentage of cells with high mitochondrial membrane potential $\left(\psi_{\mathrm{m}}\right)$ (data not shown). This synergistic induction of apoptosis was also observed in
CLL cells exposed to TRAIL, but not CD95 (Figure 1a and b). The synergy was observed when CLL cells were pretreated with nontoxic concentrations of either Trichostatin $A$ or depsipeptide (Figure 1b). We have observed this marked enhancement of apoptosis in all patients studied $(n=18)$, although some patient variation was observed (Figure 1b). Almost all CLL cells were sensitized to apoptosis as treatment with TRAIL for longer periods of time $(8 \mathrm{~h})$ resulted in more apoptosis (Figure $1 \mathrm{~b}$ and Table 1 ). Similarly, an initial longer pretreatment with depsipeptide $(16 \mathrm{~h})$ also resulted in a greater sensitivity of CLL cells to TRAIL (Table 1).

\section{HDAC inhibitors potentiate death receptor- induced apoptosis}

As TRAIL, CD95 and HDAC inhibitors can separately induce apoptosis, it was important to clarify whether HDAC inhibitors potentiated death receptor-induced apoptosis or vice versa. Following pretreatment with nontoxic concentrations of depsipeptide or Trichostatin $A$ and subsequent exposure to nontoxic concentrations of either CD95 or TRAIL, we observed increased apoptosis in both wild-type- and Bcl-XLoverexpressing, but not in caspase-8-deficient, Jurkat cells (Figure 1c). Z-VAD.fmk (25 $\mu \mathrm{M})$, which does not inhibit loss of mitochondrial membrane potential induced by agents that activate the intrinsic pathway, completely inhibited the augmented apoptosis assessed by either PS externalization or loss of mitochondrial membrane potential (data not shown). In Bcl-XL-overexpressing cells, apoptosis induced by higher concentrations of either depsipeptide or TSA alone, but not by TRAIL or CD95, was inhibited, whereas in caspase-8deficient Jurkat cells apoptosis induced by TRAIL or CD95, but not depsipeptide or Trichostatin A, was inhibited (Figure 1c and data not shown). Taken together, these data support the hypothesis that depsipeptide and Trichostatin A potentiated CD95- and TRAIL-induced apoptosis in Bcl-XL-overexpressing Jurkat cells.

We determined the kinetics of TRAIL-induced apoptosis following pretreatment with depsipeptide. Jurkat cells were pretreated for $8 \mathrm{~h}$ with depsipeptide $(10 \mathrm{nM})$, then exposed to TRAIL for up to $4 \mathrm{~h}$. Marked loss of mitochondrial membrane potential was observed as early as $30 \mathrm{~min}$ after exposure to TRAIL, and clearly preceded PS externalization (Figure 1d and e). The enhanced apoptosis assessed by both these criteria was almost completely blocked by the broad-spectrum caspase inhibitor, Z-VAD.fmk $(10 \mu \mathrm{M})$, whereas $\mathrm{M}-791$ $(25 \mu \mathrm{M})$, a more specific caspase-3 inhibitor, ${ }^{39}$ inhibited

Figure 1 HDAC inhibitors potentiate TRAIL-induced apoptosis. (a) Jurkat cells or freshly isolated and purified CLL cells from patients were preincubated for $8 \mathrm{~h}$ either alone or with depsipeptide. Cells were then treated with TRAIL for a further $4 \mathrm{~h}$ and apoptosis assessed by measurement of PS externalization as described in Materials and methods. (b) CLL cells were incubated for $8 \mathrm{~h}$ with either depsipeptide (Dep) $(10 \mathrm{nM})$ or TSA $(0.25 \mu \mathrm{M})$, and then treated for a further $4 \mathrm{~h}$ with either TRAIL $(0.1 \mu \mathrm{g} /$ $\mathrm{ml}$ ) or CD95 $(0.1 \mu \mathrm{g} / \mathrm{ml})$ unless otherwise indicated and apoptosis assessed by measurement of PS externalization. Data shown are from 10 individual patients, but not all experimental variables were carried out on cells from each patient. (c) Pretreatment with either depsipeptide (Dep) (10 nM) or TSA (0.25 $\mu \mathrm{M})$ markedly potentiated TRAIL- or CD95-induced apoptosis in wild-type (diagonal shading) and Bcl-XL (open bars), but not in caspase-8-deficient (horizontal shading) Jurkat cells. Wild-type E6.1 Jurkat cells were treated with TRAIL $(20 \mathrm{ng} / \mathrm{ml})$ or CD95 $(10 \mathrm{ng} / \mathrm{ml})$, whereas Bcl-XL-overexpressing and caspase-8-deficient Jurkat cells were exposed to TRAlL $(100 \mathrm{ng} / \mathrm{ml})$ or CD95 $(50 \mathrm{ng} / \mathrm{ml})$. (d) Jurkat cells were treated with either TRAIL alone $(\boldsymbol{\Delta}-\boldsymbol{\Delta})$ or pretreated with depsipeptide (Dep) $(\triangle-\triangle)$ prior to exposure to TRAIL and apoptosis assessed by loss of mitochondrial membrane potential $\left(\psi_{\mathrm{m}}\right)$. (e) Jurkat cells were treated with either TRAIL alone $(\square-\square)$ or pretreated with depsipeptide (Dep) (- ) prior to exposure to TRAIL and apoptosis assessed by an increase in PS externalization. In (d, e), Z-VAD.fmk inhibited both PS externalization and loss of $\psi_{\mathrm{m}}$, whereas the caspase-3 specific inhibitor M-791 only inhibited PS externalization 
apoptosis assessed by PS externalization, but not by loss of mitochondrial membrane potential (Figure 1d and e). These results clearly demonstrate that, in this model, loss of mitochondrial membrane potential is independent of caspase-3 activation and precedes the externalization of PS, which is dependent on caspase- 3 activation.

\section{HDAC inhibitors potentiate TRAIL-induced caspase processing}

Next we examined the temporal activation of caspases in the presence or absence of caspase inhibitors in order to confirm that the mode of cell death was apoptosis and to ascertain the

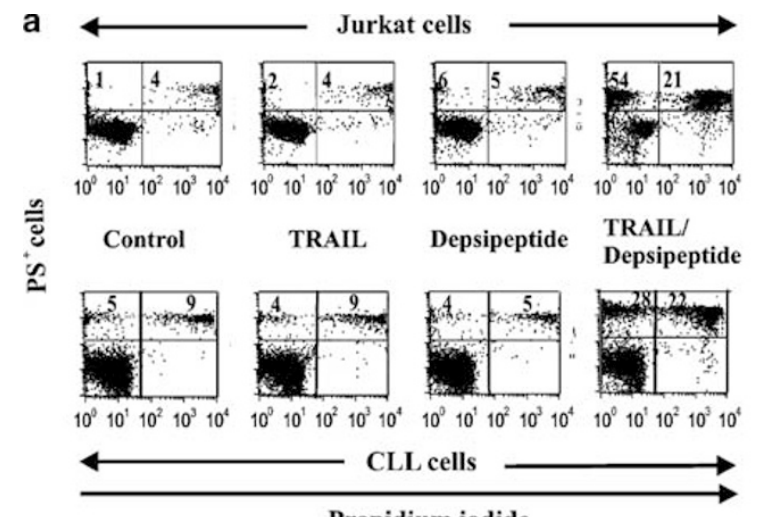

Propidium iodide

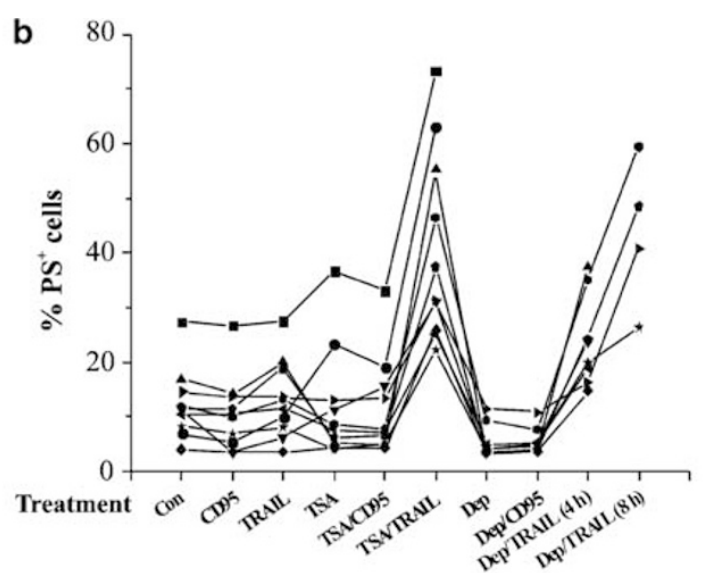

C
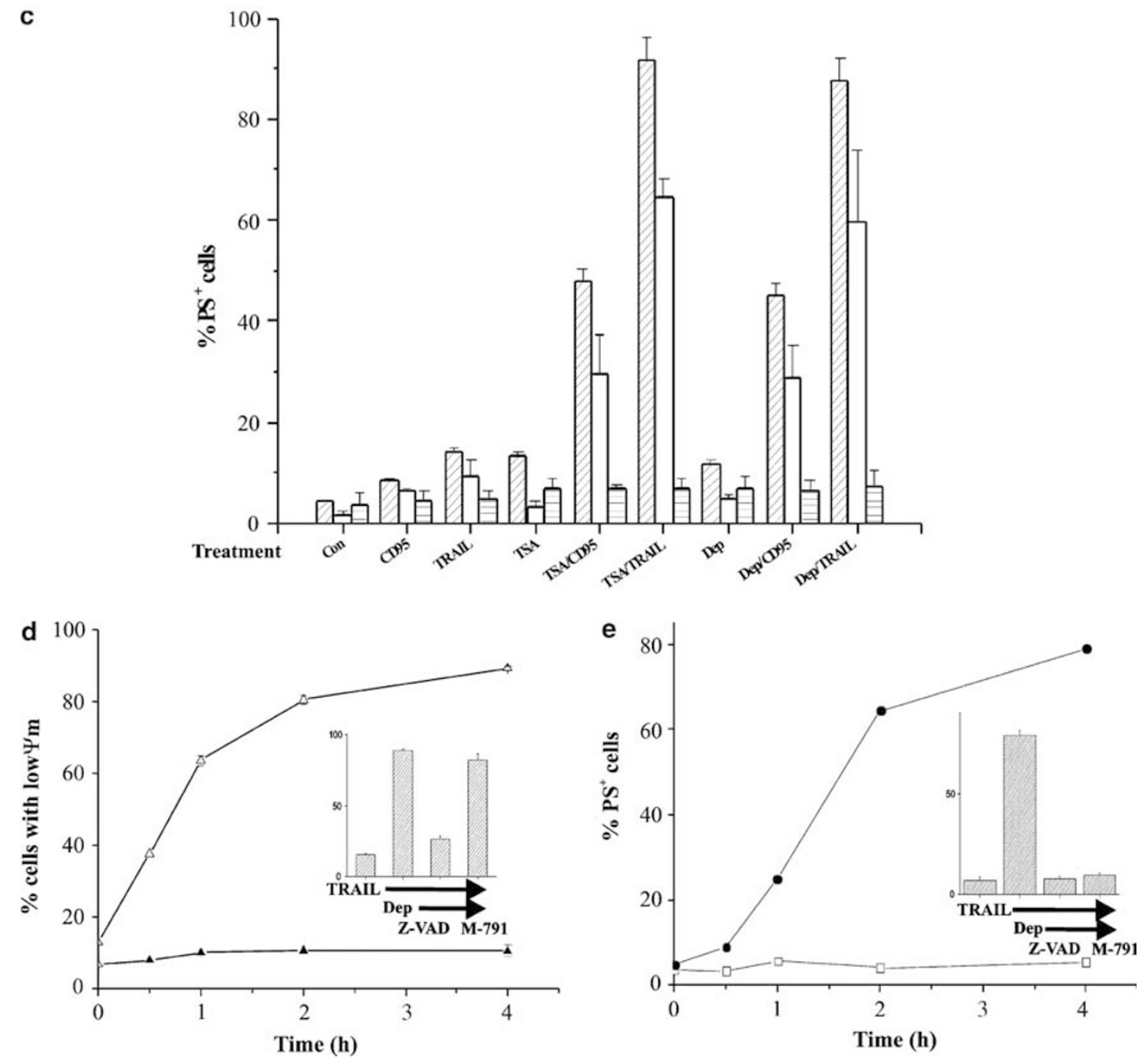


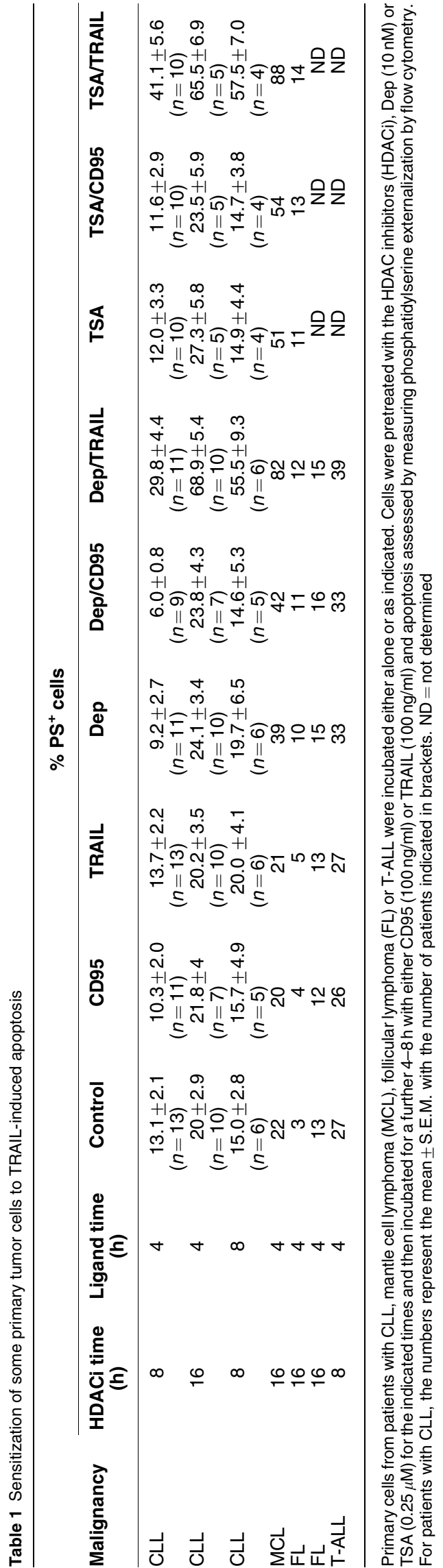

apical initiator caspase. Caspase-3, -7, -8 and -9 were present in control CLL and Jurkat cells primarily as their unprocessed zymogens, and were largely unaltered following treatment for $8 \mathrm{~h}$ with nontoxic concentrations of either depsipeptide $(10 \mathrm{nM})$ or TRAIL (Figure $2 \mathrm{a}$ and $\mathrm{b}$, lanes 1-3). After pretreatment with depsipeptide, TRAIL $(20 \mathrm{ng} / \mathrm{ml})$ induced a time-dependent processing of all these caspases (Figure $2 a$, lanes $4-7$, and $2 b$, lanes 4-6). Caspase-8 was processed to its p43 and p41 forms and at later times to its p18 large subunit (Figure $2 b$, lane 6 ); caspase-3 was processed initially to its p20 and p19 forms, followed by more extensive processing to

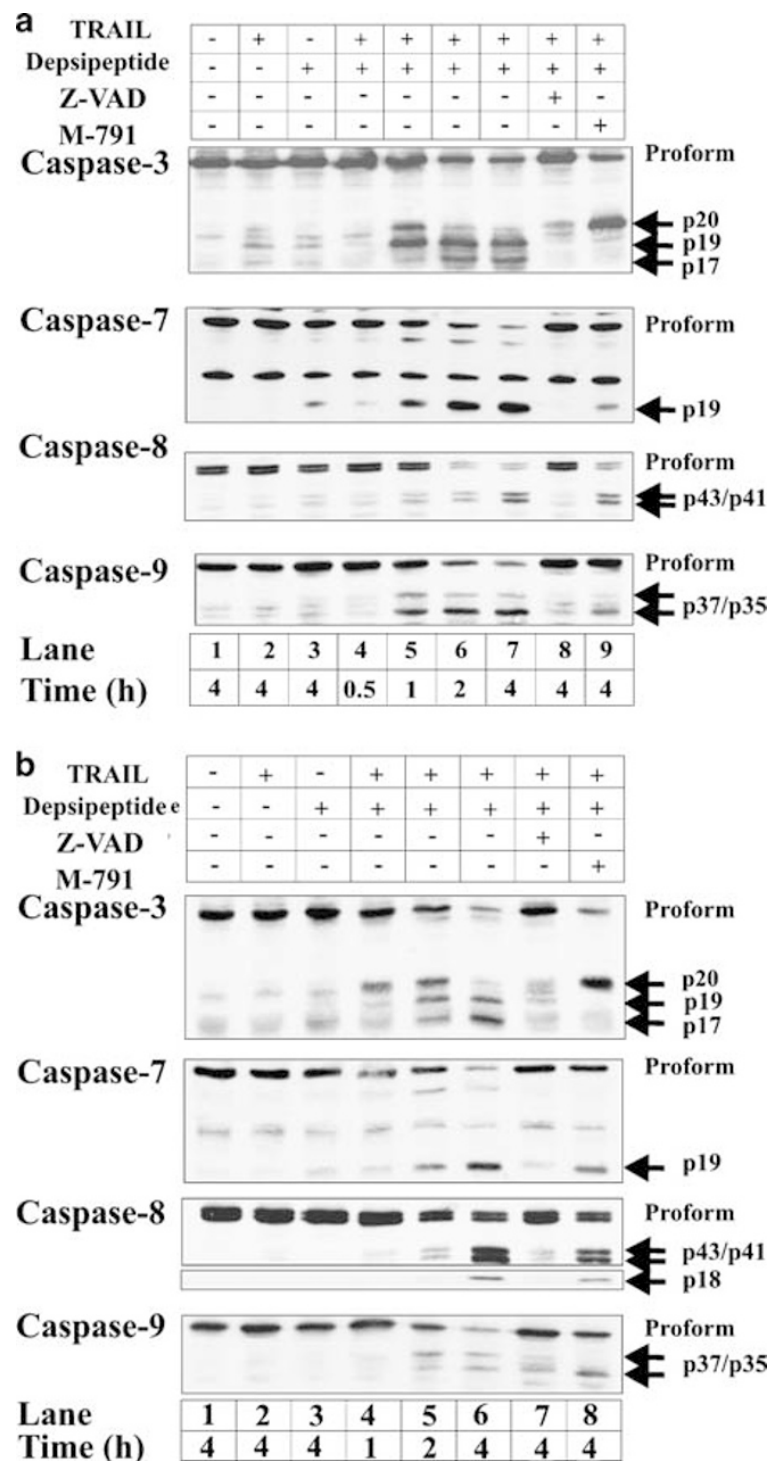

Figure 2 Depsipeptide potentiates caspase processing in Jurkat and CLL cells. (a) Jurkat and (b) CLL cells were incubated for $4 \mathrm{~h}$ either alone (lane 1), with TRAIL or depsipeptide $(10 \mathrm{nM})$ (lanes 1-3, respectively). Cells treated with depsipeptide were then exposed to TRAIL (20 and $100 \mathrm{ng} / \mathrm{ml}$ for Jurkat and CLL cells, respectively) for the indicated times either alone or in the presence of Z-VAD.fmk or M-791. The processing of caspase-3, -7, -8 and -9 was then assessed by Western blotting as described in Materials and methods. In (b), the lower blot for caspase-8 shows its processing to the catalytically active p18 large subunit. The data shown in (b) are from a patient who showed a strong potentiation in the presence of depsipeptide 
its p19 and p17 forms; by $1 \mathrm{~h}$, caspase-7 was clearly processed to its p19 large subunit (Figure 2a, lanes 4-7, and $2 b$, lanes $4-6$ ). Caspase- 9 was processed to both its p35 and p37 forms following Apaf-1- and caspase-3-mediated cleavage at Asp 315 and Asp 330, respectively. ${ }^{40}$ We observed marked differences in caspase processing in the presence of both caspase inhibitors. Z-VAD.fmk largely or completely blocked the increased processing of all the caspases (Figure 2a, lane 8, and 2b, lane 7). Our observation that Z-VAD.fmk almost completely inhibited the processing of caspase-3 provided strong support for the hypothesis that caspase- 8 is the apical caspase, as Z-VAD.fmk only inhibits the processing of caspase- 3 to its $p 19 / p 17$ forms but retains the 20 form when caspase- 9 is the apical caspase. ${ }^{41}$ In the presence of $M-791$, caspase- 8 was still clearly processed to its p43, p41 and p18 forms although some diminution in the amount of processing was observed most probably due to inhibition of a feed-forward amplification loop mediated by caspase-3 (Figure 2a, lane 9, and 2b, lane 8). Caspase-3 was also still clearly processed but only to its p20 form, which was catalytically inactive in the presence of M-791 (Figure 2a, lane 9 , and $2 \mathrm{~b}$, lane 8 ). Caspase-7 and caspase-9 were both still processed, compatible with these caspases being direct substrates for activated caspase-8. ${ }^{42}$ Interestingly, the Apaf1-mediated processing of caspase- 9 to its p35 form was observed, whereas formation of the p37 form by caspase-3 was inhibited (Figure 2a, lane 9, and 2b, lane 8). Pretreatment with depsipeptide for $16 \mathrm{~h}$, followed by exposure to TRAIL, resulted in an even more rapid and extensive activation of caspases (data not shown). Taken together, these results demonstrate that in both CLL and Jurkat cells depsipeptide potentiates TRAIL-induced apoptosis and caspase- 8 is the initiator caspase.

\section{HDAC inhibitors cause a small increase in TRAIL-R2, but do not markedly alter the levels of other proteins associated with the DISC}

As we also observed the potentiation of apoptosis in $\mathrm{Bcl}-\mathrm{XL}$ overexpressing cells, it implicated some step in the apoptotic process upstream of the mitochondria, possibly an alteration in TRAIL death receptor expression or DISC formation. We examined cells exposed to HDAC inhibitors for increases in cell surface death receptor expression, as such increases have been reported following treatment with some chemotherapeutic agents and may be partly responsible for the enhanced apoptosis observed following their combination with death-inducing ligands. ${ }^{43,44}$ A small increase in the cell surface expression of TRAIL-R2 was observed, accompanied by a small decrease in both TRAIL-R1 and CD95 in CLL cells treated for 8-16 $\mathrm{h}$ with depsipeptide or for $8 \mathrm{~h}$ with Trichostatin A (Figure $3 a$ ), that is, using the same conditions that markedly potentiated TRAIL-induced apoptosis. Similarly, a recent study demonstrated no increase in cell surface CD95 expression in CLL cells exposed to depsipeptide. ${ }^{27}$ No marked changes were observed in the cell surface expression of TRAIL-R3 or -R4 (Figure 3a). Similar changes were observed in the cell surface expression of TRAIL receptors in Jurkat cells treated with these HDAC inhibitors (data not

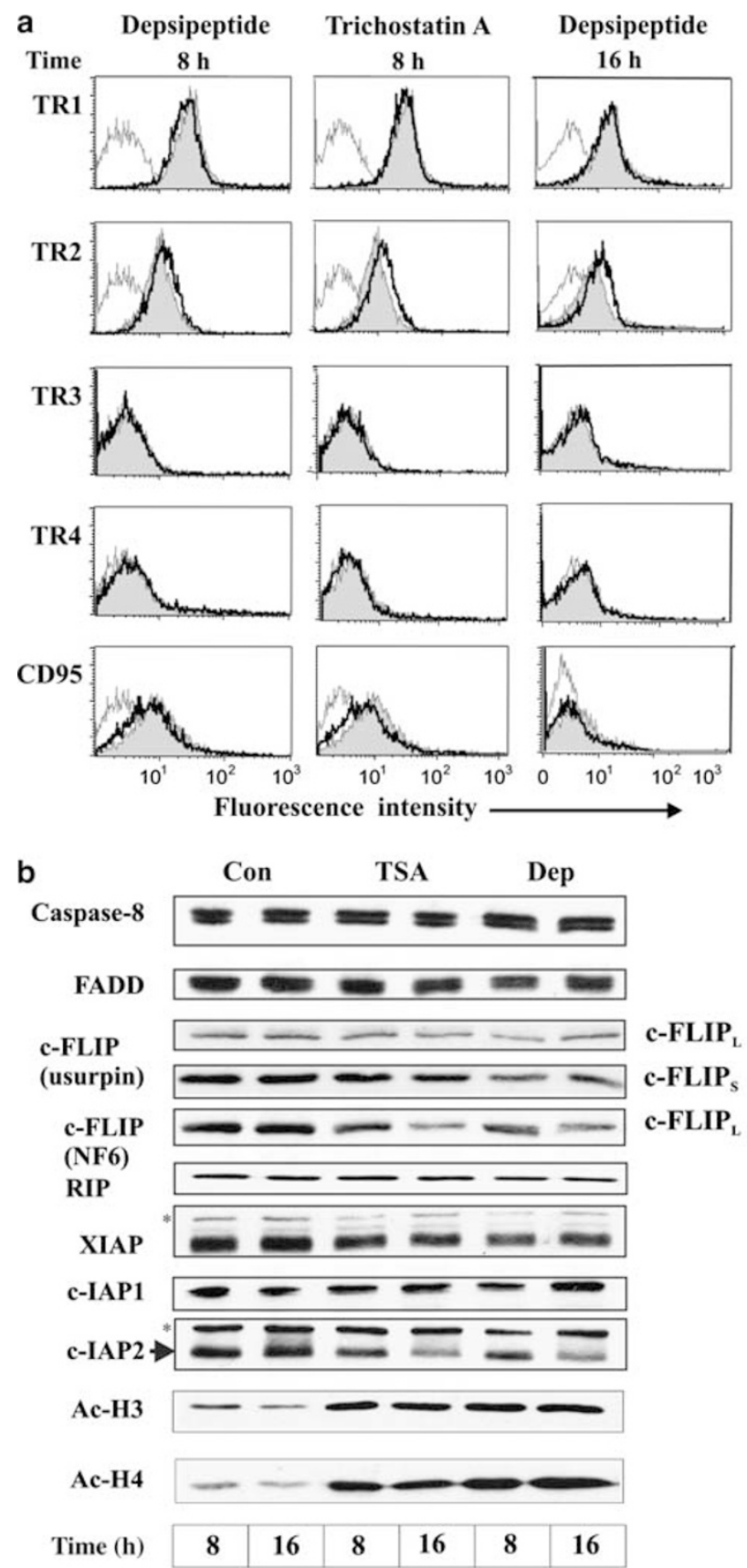

Figure 3 Effects of HDAC inhibitors on cell surface death receptor expression and major DISC components. (a) CLL cells were incubated for $8 \mathrm{~h}$ either alone (gray shading) or with depsipeptide $(10 \mathrm{nM})$ or Trichostatin $\mathrm{A}(0.25 \mu \mathrm{M})$ (dark black lines) as indicated. Cells were also incubated for $16 \mathrm{~h}$ either alone (gray shading) or with depsipeptide (10 nM) (right-hand panel) (dark black line). Cells were harvested and cell surface receptor expression assessed by flow cytometry using monoclonal antibodies to TRAIL (TR) receptors 1-4 and CD95. Cells labelled with secondary antibody alone were used to control for background fluorescence (pale line - no shading). (b) CLL cells were incubated for the indicated times either alone (Con), with TSA or with depsipeptide (Dep) and then analyzed by Western blotting for components of the DISC or inhibitors of apoptosis. Two different antibodies were used for analysis of c-FLIP 
shown). As some studies in the literature have reported that an upregulation of receptors may lead to an increased sensitivity to TRAIL, we examined whole-cell samples to give us a measurement of intracellular receptors as well as cell surface expression. It was possible that the treatment with the HDAC inhibitors (see later) could cause an increase in intracellular receptors, thus facilitating transport to the plasma membrane with a resultant greater susceptibility to apoptosis. Taken together, these data suggest that the small increase in cell surface expression of TRAIL-R2 may contribute at least in part to the increased TRAIL sensitivity of CLL cells.

We then examined the effects of depsipeptide on other well-characterized proteins associated with the TRAIL DISC, namely FADD, caspase-8, c-FLIP and RIP. Several studies have suggested that decreases in C-FLIP sensitize cells to death receptor-induced apoptosis, although this is somewhat controversial. ${ }^{45}$ In addition, depsipeptide has been reported to decrease c-FLIP in CLL cells. ${ }^{27}$ We also investigated changes in XIAP and C-IAP2, as their levels have been shown to decrease following exposure to some HDAC inhibitors. ${ }^{33}$ In both CLL and Jurkat cells, we found no marked changes in the levels of FADD, caspase-8, RIP or XIAP (Figure 3b and data not shown). We observed a very modest decrease in C-FLIP following treatment with HDAC inhibitors, using one antibody, but not with another (Figure $3 b$ ). Using a third antibody to C-FLIP $\mathrm{P}_{\mathrm{L}}$ (Upstate Biotechnology), no change in $\mathrm{c}-\mathrm{FLIP}_{\mathrm{L}}$ was observed following exposure to either depsipeptide or Trichostatin A (data shown to referees). A modest timedependent decrease in C-IAP2, but not C-IAP1, was observed in CLL cells exposed to these HDAC inhibitors (Figure $3 b$ ). We wished to confirm that the HDAC inhibitors were inhibiting HDACs in CLL cells. The low concentrations of Trichostatin A or depsipeptide used inhibited HDAC activity, as assessed by their ability to induce histone $\mathrm{H} 3$ and $\mathrm{H} 4$ acetylation (Figure $3 \mathrm{~b}$ ) in agreement with previous findings. ${ }^{27}$ Both Trichostatin $A$ $(0.25 \mu \mathrm{M})$ and depsipeptide $(10 \mathrm{nM})$ caused a time-dependent accumulation of histone $\mathrm{H} 4$ acetylation. Marked accumulation was first observed 1-2 and 2-4 h following Trichostatin A and depsipeptide treatment, respectively (data not shown). Taken together, our data supported the suggestion that the increase in cell surface expression of TRAIL-R2, but not alterations in the levels of any of the other major DISC components, may be partly responsible for the marked sensitization of CLL cells by HDAC inhibitors to TRAIL-induced apoptosis.

\section{HDAC inhibitors sensitize cells to TRAlL-induced apoptosis by increased DISC formation}

As formation of a DISC is often rate limiting in death receptorinduced apoptosis, we therefore examined formation of the TRAIL DISC using biotinylated TRAIL. Biotinylated TRAIL induced a time-dependent formation of the DISC in control and depsipeptide-pretreated CLL cells. A marked increase in both the levels of TRAIL-R2 and also in the recruitment of FADD and caspase-8 to the TRAIL DISC was observed in CLL cells pretreated with depsipeptide for $16 \mathrm{~h}$ (Figure $4 \mathrm{a}$, right panel). Similar but less dramatic changes were observed when cells were pretreated with depsipeptide for $8 \mathrm{~h}$ (Figure 4a, left panel). In DISCs isolated from depsipeptide-

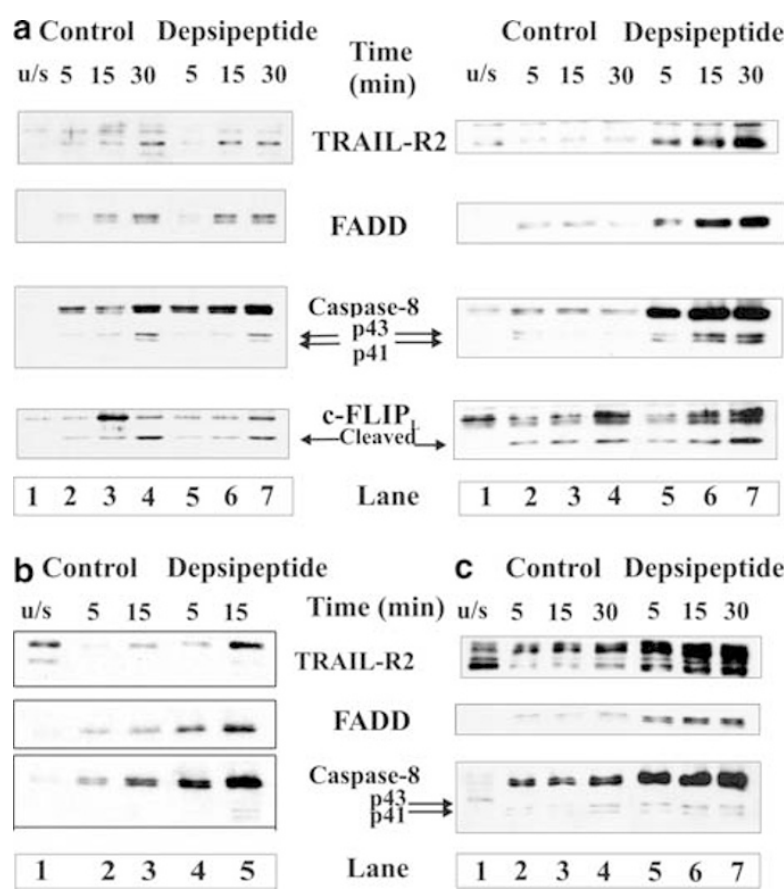

Figure 4 HDAC inhibitors potentiate formation of TRAIL DISC in CLL cells. (a) $\mathrm{CLL}$ cells were incubated for $8 \mathrm{~h}$ (left panel) or $16 \mathrm{~h}$ (right panel) either alone (Control) or in the presence of depsipeptide $(10 \mathrm{nM})$. Cells were then exposed to biotinylated TRAIL $(500 \mathrm{ng} / \mathrm{ml})$ for the indicated times and a DISC isolated as described in Materials and methods. To provide an unstimulated receptor control, biotinylated TRAIL was added to lysate from untreated cells (u/s). The DISCs obtained were analyzed by Western blotting. (b) Jurkat cells were incubated for $8 \mathrm{~h}$ with depsipeptide $(10 \mathrm{nM})$ and then exposed to biotinylated TRAIL (100 ng/ $\mathrm{ml}$ ) and a native DISC isolated as described in (a). (c) U937 cells were incubated for $8 \mathrm{~h}$ either alone (Control) or in the presence of depsipeptide $(10 \mathrm{nM})$. Cells were then exposed to biotinylated TRAIL $(500 \mathrm{ng} / \mathrm{ml})$ for the indicated times and a DISC isolated as described in Materials and methods. To provide an unstimulated receptor control, biotinylated TRAIL was added to lysate from untreated cells (u/s). The DISCs obtained were analyzed by Western blotting

pretreated cells, caspase- 8 was processed to both its p43 and p41 forms much more readily than in control cells (Figure 4a, compare lanes 5-7 to 2-4). Caspase-8 observed in the depsipeptide-pretreated cells also appeared to be catalytically active as processed caspase- 8 was found in the cytosol (Figure 2b). Similar levels of $c-$ FLIP $_{L}$ were recruited to the DISC in CLL cells treated with TRAIL alone or those pretreated with depsipeptide (Figure 4a, compare lanes 2-4 to 5-7). Additionally, in both the control and pretreated cells, C-FLIP $\mathrm{L}_{\mathrm{L}}$ was cleaved by caspase-8 to form an $\sim 43 \mathrm{kDa}$ fragment, which probably represents the product obtained following removal of the C-terminal $\mathrm{p} 10$ subunit $^{15}$ (Figure $4 \mathrm{a}$ ). We thus observed an increase in the caspase-8/FLIP ratio in the DISC in the depsipeptide-treated cells, compatible with our previous suggestion that this ratio may be important in determining sensitivity to TRAIL-induced apoptosis. ${ }^{20,46}$ However, our results did not support a critical role for a decrease in c-FLIP being responsible for the marked sensitization of CLL cells to TRAIL. We then examined Jurkat cells to see if pretreatment with depsipeptide also facilitated DISC formation. Jurkat cells were cultured for $8 \mathrm{~h}$ either alone or with depsipeptide $(10 \mathrm{nM})$ and then treated with biotinylated TRAIL for $5-15 \mathrm{~min}$ and the native TRAIL DISC isolated. 
Jurkat cells pretreated with depsipeptide also showed an increase in the levels of TRAIL-R2 and recruitment of FADD and caspase- 8 compared to control cells (Figure $4 \mathrm{~b}$, compare lanes 4 and 5 with lanes 2 and 3). Taken together, these data support the hypothesis that depsipeptide sensitization of CLL and Jurkat cells to TRAIL-induced apoptosis resulted from an increased formation of the TRAIL DISC accompanied by increased recruitment of FADD and activation of caspase-8.

\section{Depsipeptide sensitizes some resistant tumor cells to TRAIL}

As depsipeptide could sensitize CLL and Jurkat cells to TRAIL, we wished to see if it could also sensitize other TRAIL-resistant cells, such as the monocytic leukemic cell line U937. Exposure of U937 cells for $8 \mathrm{~h}$ to depsipeptide $(10 \mathrm{nM})$ alone or to TRAIL for $4 \mathrm{~h}$ did not induce apoptosis $(7.6 \pm 1.4$ and $5.6 \pm 0.9 \%$, respectively) (mean \pm S.E.M., $n=5$ ). However, when U937 cells were pretreated with depsipeptide for $8 \mathrm{~h}$ and then exposed to TRAIL for a further $4 \mathrm{~h}$, a marked sensitization to TRAIL-induced apoptosis was observed $(44 \% \pm 0.9$, mean \pm S.E.M., $n=5)$. Treatment with TRAIL resulted in the time-dependent formation of a native TRAIL DISC with significantly more DISC formed in U937 cells pretreated with depsipeptide (Figure 4c). This greater formation of the TRAIL DISC was accompanied by increased levels of TRAIL-R2, FADD and caspase- 8 within the DISC and a higher caspase-8/C-FLIPL ratio. No differences were observed in the amount of $\mathrm{C}-\mathrm{FLIP}_{\mathrm{L}}$ recruited to the DISC in control and depsipeptide-pretreated cells (data not shown). In preliminary experiments, we have also examined the sensitivity of some other primary $\mathrm{B}$ - and $\mathrm{T}$-cell tumor cells from patients to the combination of HDAC inhibitors and TRAIL. Cells from a patient with mantle cell lymphoma were sensitized, but not cells from patients with follicular lymphoma or T-cell precursor acute lymphoblastic leukemia (T-ALL) (Table 1).

\section{HDAC inhibitors do not sensitize normal B cells to TRAIL-induced apoptosis}

Many reports have described the selective toxicity of TRAIL to cancer cells compared to normal cells. Our finding that HDAC inhibitors potentiate TRAIL-induced apoptosis in CLL cells is particularly important because initial studies suggest these inhibitors are relatively nontoxic in vivo and also are selectively toxic to tumor cells. ${ }^{24,25}$ In order to test the potential toxicity of the combination to normal cells, we examined the toxicity of depsipeptide and TRAIL to both freshly isolated normal $B$ and T cells. Depsipeptide, TSA or TRAIL alone were generally nontoxic to normal $B$ cells from healthy volunteers. In 6/7 samples, depsipeptide or TSA caused very little potentiation of TRAIL-induced apoptosis in normal B cells (Figure 5a) compared to CLL cells. In the T cells, although some toxicity was observed with the HDAC inhibitors alone (depsipeptide and TSA were slightly toxic in $2 / 6$ and $1 / 6$ samples, respectively), no sensitization of TRAILinduced apoptosis was observed with either HDAC inhibitor in
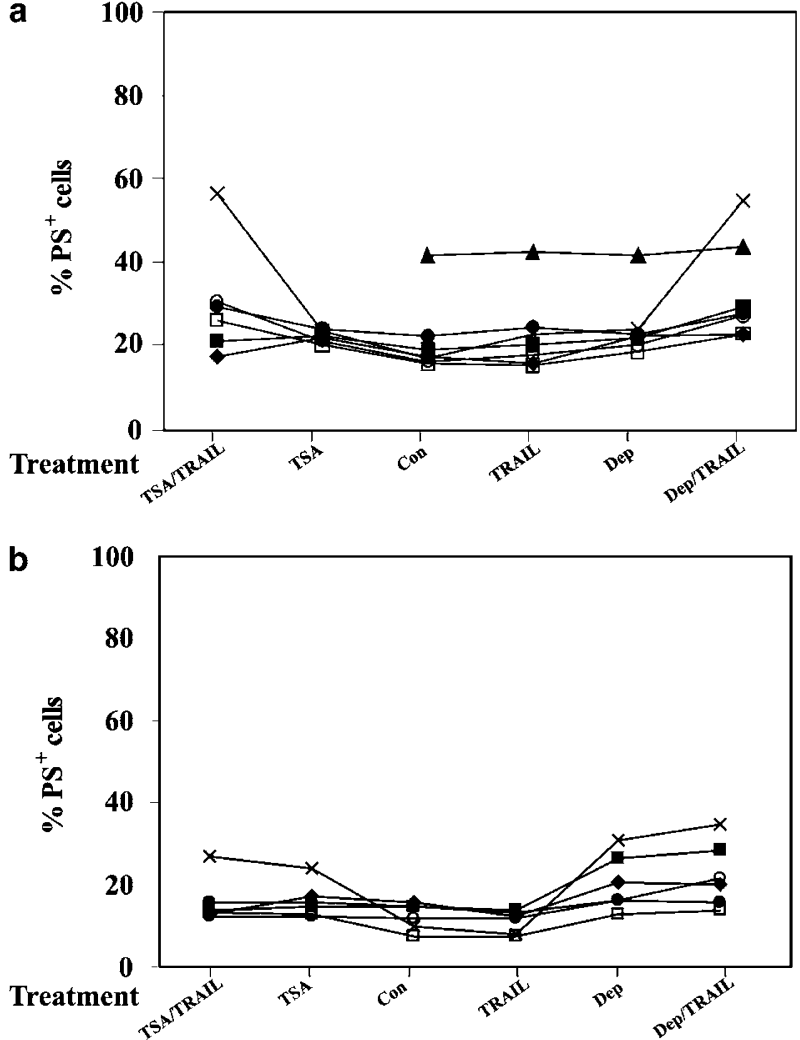

Figure 5 HDAC inhibitors do not sensitize normal $B$ and T cells to TRAlLinduced apoptosis. Enriched (a) B cells and (b) T cells from normal volunteers were pretreated for $8 \mathrm{~h}$ with either depsipeptide (Dep) (10 nM) or Trichostatin A (TSA) $(0.25 \mu \mathrm{M})$ and then exposed for a further $4 \mathrm{~h}$ to TRAIL $(100 \mathrm{ng} / \mathrm{ml})$. Apoptosis was then assessed by PS externalization using flow cytometry. Incubation with the HDAC inhibitor together with TRAIL for a further $4 \mathrm{~h}$ did not induce apoptosis

all samples examined (Figure 5b). Taken together, these results indicate that HDAC inhibitors do not sensitize most normal $B$ or T cells to TRAIL-induced apoptosis.

\section{HDAC inhibitors potentiate the toxicity of some chemicals}

In addition to the ability of HDAC inhibitors to sensitize cells to TRAIL-induced apoptosis, it was possible that these cells were also sensitized to agents that activate the intrinsic pathway. Pretreatment of Jurkat cells with depsipeptide resulted in a significant potentiation of apoptosis induced by the PKC inhibitor bisindolylmaleimide IX, the cyclin-dependent kinase inhibitor flavopiridol and the proteasome inhibitor MG132 (Figure 6a). Pretreatment with depsipeptide resulted in only a modest potentiation of apoptosis induced by these agents in CLL cells (Figure 6a). As the induction of apoptosis by TRAIL in several cellular systems requires Bax and/or a mitochondrial component, ${ }^{47,48}$ it was possible that part of the sensitization by HDAC inhibitors was also due to an effect, either directly or indirectly, on mitochondria. In addition, higher concentrations of HDAC inhibitors alone induce apoptosis by perturbation of mitochondria and activation of the intrinsic pathway. ${ }^{28-30}$ In this respect, we initially examined cells 
a
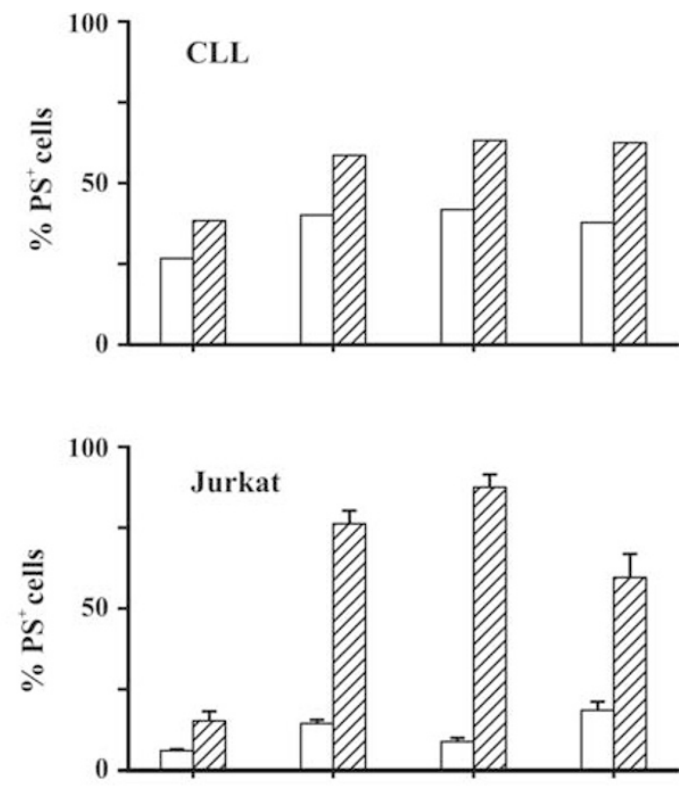

\begin{tabular}{|c|c|c|c|c|}
\hline Depsipeptide & -+ & -+ & -+ & -+ \\
\hline Bis IX & -- & ++ & -- & -- \\
\hline Flavopiridol & -- & -- & ++ & -- \\
\hline MG132 & -- & -- & -- & ++ \\
\hline
\end{tabular}

b
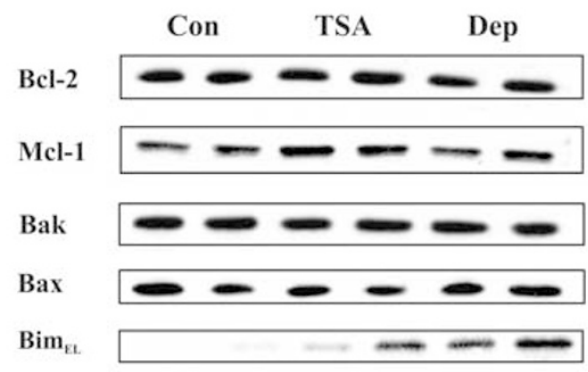

\begin{tabular}{|l|l|l|l|l|l|l|}
\hline Time (h) & 8 & 16 & 8 & 16 & 8 & 16 \\
\hline
\end{tabular}

Figure 6 HDAC inhibitors sensitize cells to chemical-induced apoptosis. (a) Jurkat cells were incubated either alone or in the presence of depsipeptide $(10 \mathrm{nM})$ for $8 \mathrm{~h}$ and then exposed for $4 \mathrm{~h}$ to either bisindolylmaleimide IX (Bis IX) $(1 \mu \mathrm{M})$, flavopiridol $(50 \mathrm{nM})$ or MG132 $(1 \mu \mathrm{M})$. Similarly, CLL cells were incubated either alone or in the presence of depsipeptide $(10 \mathrm{nM})$ for $16 \mathrm{~h}$ and then exposed for a further $4 \mathrm{~h}$ to the chemicals as indicated. Apoptosis was then assessed by measuring the cells with increased PS externalization. (b) CLL cells were incubated for the indicated times either alone (Con), with TSA or with depsipeptide (Dep) and then analyzed for pro- and antiapoptotic Bcl-2 family members by Western blotting

pretreated with HDAC inhibitors for altered expression of Bcl2 family members. No marked changes were observed in the major antiapoptotic (Bcl-2 and $\mathrm{Mcl}-1)$, and proapoptotic (Bax and Bak) Bcl-2 family members in CLL cells except for a timedependent increase in Bim $\mathrm{EL}_{\mathrm{L}}$ a proapoptotic BH3-onlycontaining protein (Figure $6 b$ ). Bim $L$ was also present in CLL cells, but did not appear to be altered following treatment with HDAC inhibitors (data not shown). Similarly, in Jurkat cells which express both $\mathrm{Bim}_{\mathrm{EL}}$ and $\mathrm{Bim}_{\mathrm{L}},{ }^{49}$ pretreatment with the HDAC inhibitors resulted in an increase in Bim $E L$ (data not shown).

\section{Sensitization to HDAC inhibitors is not primarily due to increased levels of TRAIL-R2}

We wished to examine if the observed increase in cell surface expression of TRAIL-R2 (Figures 3a) was responsible for the marked sensitization to TRAIL-induced apoptosis. Exposure of U937 cells to depsipeptide also resulted in a timedependent increase in TRAIL-R2 levels (Figure 7a, lanes 4-7). This increase was due to de novo protein synthesis as it was prevented by pretreatment with cycloheximide $(\mathrm{CHX}$; Figure 7a, lanes 8 and 9). This experimental approach offered a means to ascertain the importance of the increased TRAILR2 levels in the sensitization.

The use of $\mathrm{CHX}$ to investigate the role of increased TRAILR2 levels in the sensitization to TRAIL-induced apoptosis is inherently difficult because $\mathrm{CHX}$ alone can sensitize to TRAILinduced apoptosis, probably due to inhibition of NF- $\kappa$ B. Thus, after the initial treatment of cells with $\mathrm{CHX}$ to inhibit protein synthesis and the upregulation of TRAIL-R2, the cells were then washed with medium in order to minimize any possible effects of $\mathrm{CHX}$ on TRAIL-induced apoptosis. Cells were treated for $8 \mathrm{~h}$ in the presence or absence of depsipeptide $(10 \mathrm{nM})$, with or without $\mathrm{CHX}$, and then washed. Cells were then cultured for a further $4 \mathrm{~h}$ in the presence or absence of TRAIL and apoptosis assessed. Firstly, in the absence of depsipeptide, pretreatment with $\mathrm{CHX}(2.5$ and $5 \mu \mathrm{M})$ resulted in a potentiation of TRAIL-induced apoptosis, but this was almost completely reversed by the wash-out of $\mathrm{CHX}$ after $8 \mathrm{~h}$ (Figure 7b, left panel). In marked contrast, the depsipeptidemediated sensitization of U937 cells to TRAIL was not reversed by washing (Figure $7 \mathrm{~b}$, right panel). Most importantly, depsipeptide still sensitized U937 cells to TRAILinduced apoptosis even when incubated in the presence of $\mathrm{CHX}$ and following wash-out (Figure $7 \mathrm{~b}$, right panel). Thus, the sensitization of TRAIL-induced apoptosis by depsipeptide occurred in the absence of any increase in TRAIL-R2, suggesting that the increase in TRAIL-R2 is not required for the increase in apoptosis in U937 cells.

We wished to confirm that a similar phenomenon was also occurring in CLL cells, although these studies are more difficult to carry out in primary CLL cells partly due to varying levels of spontaneous apoptosis and also because of the partial sensitivity of CLL cells to CHX-induced apoptosis. ${ }^{20}$ Depsipeptide again caused a time-dependent increase in TRAIL-R2 levels in CLL cells (Figure 7c, lanes 5 and 8), which was due to de novo protein synthesis, as it was completely prevented by cotreatment with $\mathrm{CHX}$ (Figure 7c, lanes 6 and 9). In addition, in preliminary studies with CLL cells, cotreatment with $\mathrm{CHX}$ completely prevented the depsipeptide-induced increase of cell surface expression of TRAIL-R2 as measured by flow cytometry (data not shown). CLL cells from six different patients were then exposed for $16 \mathrm{~h}$ to depsipeptide either in the presence or absence of $\mathrm{CHX}$, followed by washing and exposure to TRAIL for a further $4 \mathrm{~h}$ when apoptosis was assessed. The current experimental protocol of incubation with $\mathrm{CHX}$ for only $16 \mathrm{~h}$ resulted in only a minimal effect on TRAIL-induced apoptosis (Figure 7d, compare lanes 2 and 4) compared to a more extensive induction of apoptosis resulting from longer incubations of up to $42 \mathrm{~h}$ with $\mathrm{CHX}{ }^{20}$ Depsipeptide alone again caused a marked sensitization of 
CLL cells to TRAIL-induced apoptosis (Figure 7d, lane 6). When CLL cells were preincubated with TRAIL in the presence of $\mathrm{CHX}$ followed by washing, TRAIL again caused a marked induction of apoptosis (Figure 7d, lane 8) although it was somewhat less than in the absence of CHX. Thus, in CLL cells, the major part of the sensitization to TRAIL-induced apoptosis by depsipeptide occurred independently of the upregulation of TRAIL-R2, although there also appeared to be a small but significant contribution of the increased TRAIL-R2. Although the data from both U937 and CLL cells suggested there may be some cell type differences, taken together, these data strongly suggest that the HDAC inhibitor-induced sensitization to TRAIL-induced apoptosis is not due primarily to an upregulation of TRAIL-R2 receptor levels.

\section{DISC formation is facilitated in the presence of depsipeptide and $\mathrm{CHX}$}

As the HDAC inhibitor-induced sensitization to TRAILinduced apoptosis did not appear to be primarily due to an upregulation of TRAIL-R2 receptor levels, we wished to examine whether formation of the DISC was still enhanced in the presence of $\mathrm{CHX}$. U937 cells were again cultured either alone or in the presence of depsipeptide $(10 \mathrm{nM})$ with or without $\mathrm{CHX}$ and the time-dependent formation of the native TRAIL DISC was examined (Figure 8a). Treatment with depsipeptide alone again caused increased levels of TRAILR2, FADD and caspase- 8 within the DISC compared to control cells (Figure 8a, compare lanes 5 and 6 with lanes 2 and 3). When the U937 cells were preincubated with depsipeptide in the presence of $\mathrm{CHX}$, the increase in TRAIL-R2 was completely abolished, but an increase in FADD recruitment and caspase- 8 processing was still observed (Figure 8a, lanes 8 and 9), although this was somewhat less than in the presence of depsipeptide alone. These results strongly supported the suggestion that the HDAC inhibitor facilitated recruitment of FADD and caspase-8 to the DISC was not dependent on increased TRAIL-R2 expression.

In order to determine if the facilitated DISC formation in the absence of increased TRAIL-R2 expression was cell type specific, we repeated these studies in K562 chronic myeloid leukemic cells, another relatively TRAIL-resistant cell line.

Figure 7 Sensitization to TRAIL-induced apoptosis is not due to upregulation of TRAIL-R2. (a) U937 cells were incubated either alone or with depsipeptide (Dep) $(10 \mathrm{nM})$ for the indicated times in the presence or absence of different concentrations of $\mathrm{CHX}$. Cells were then analyzed for the presence of TRAIL-R2 by Western blot analysis as described in Materials and Methods. (b) U937 cells were treated for $8 \mathrm{~h}$ in the presence or absence of depsipeptide $(10 \mathrm{nM})$ with or without $\mathrm{CHX}$ and then washed, where indicated, to remove the chemicals. Cells were then cultured for a further $4 \mathrm{~h}$ in the presence or absence of TRAIL $(100 \mathrm{ng} /$ $\mathrm{ml}$ ) and apoptosis assessed by externalization of PS. (c) CLL cells were incubated either alone or with depsipeptide (Dep) $(10 \mathrm{nM})$ for the indicated times in the presence or absence of $\mathrm{CHX}$. Cells were then analyzed for the presence of TRAIL-R2 by Western blot analysis as described in Materials and Methods. (d) CLL cells from six different patients were cultured for $16 \mathrm{~h}$ in the presence or absence of depsipeptide with or without $\mathrm{CHX}$ as indicated. Cells were then cultured for a further $4 \mathrm{~h}$ in the presence or absence of TRAIL and apoptosis assessed. These mean values were significantly different at $P<0.05$ level compared to TRAIL alone. *Groups 6 and 8 were significantly different
Firstly, we confirmed that these cells in the presence of $\mathrm{CHX}$ and depsipeptide behaved similarly to U937 cells. In the absence of depsipeptide, pretreatment with $\mathrm{CHX}(1 \mu \mathrm{M})$ resulted in a potentiation of TRAIL-induced apoptosis, but this was almost completely reversed by the wash-out of $\mathrm{CHX}$ after $12 \mathrm{~h}$ (Figure $8 \mathrm{~b}$, lanes 2 and 3 ). However, the depsipeptide-mediated sensitization of K562 cells to TRAIL was not reversed by washing (Figure $8 b$, lanes 4 and 5 ). Most importantly, depsipeptide still sensitized K562 cells to

\begin{tabular}{|c|c|c|c|c|c|c|c|c|c|}
\hline Dep $(10 \mathrm{nM})$ & \multicolumn{3}{|c|}{ - } & \multicolumn{6}{|c|}{+} \\
\hline $\mathrm{CHX}(\mu \mathrm{M})$ & - & 2.5 & 5 & \multicolumn{4}{|c|}{-} & 2.5 & 5 \\
\hline Time (h) & 8 & 8 & 8 & 1 & 2 & 4 & 8 & 8 & 8 \\
\hline (kDa) & 7 & & & & & & & & \\
\hline $50-$ & 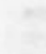 & 85 & 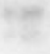 & $=4$ & +0 & 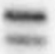 & 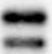 & $+x$ & a \\
\hline Lane & 1 & 2 & 3 & 4 & 5 & 6 & 7 & 8 & 9 \\
\hline
\end{tabular}
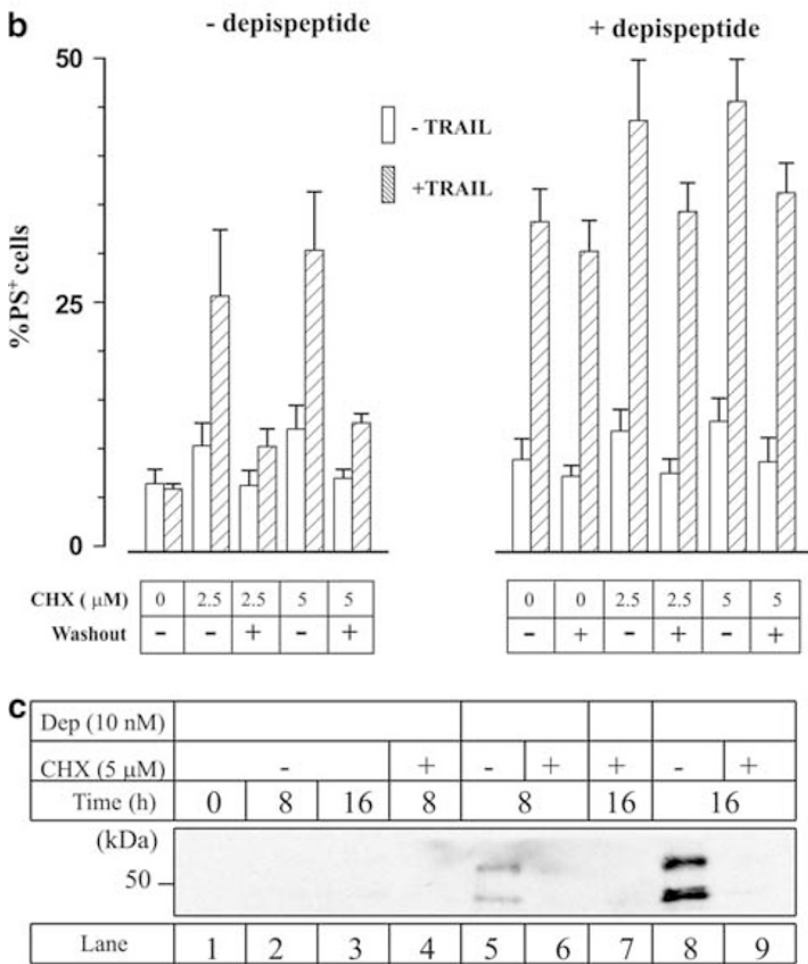

d

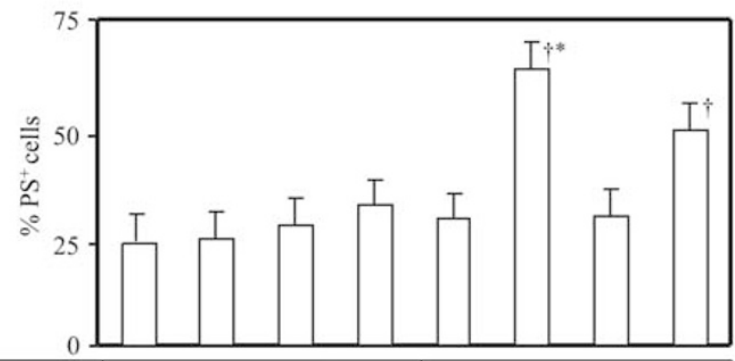

\begin{tabular}{|c|c|c|c|c|c|c|c|c|}
\hline Dep $(10 \mathrm{nM})$ & \multicolumn{4}{|c|}{-} & \multicolumn{5}{|c|}{+} \\
\hline CHX $(5 \mu \mathrm{M})$ & \multicolumn{2}{|c|}{-} & \multicolumn{2}{|c|}{+} & \multicolumn{2}{|c|}{-} & \multicolumn{2}{|c|}{+} \\
\hline TRAIL & - & + & - & + & - & + & - & + \\
\hline Lane & 1 & 2 & 3 & 4 & 5 & 6 & 7 & 8 \\
\hline
\end{tabular}




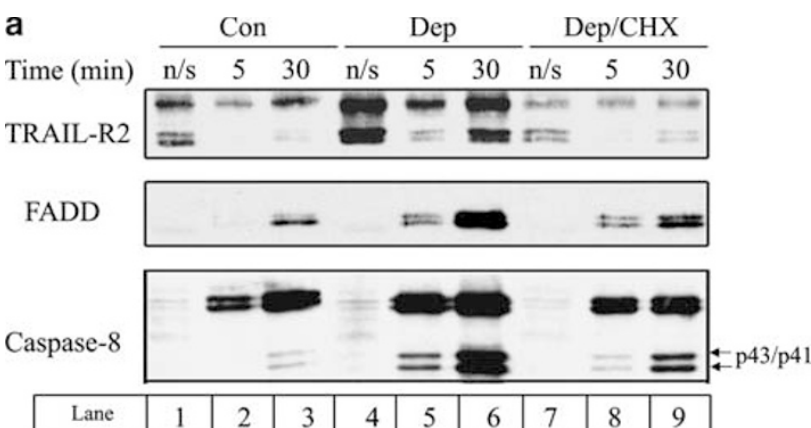

b

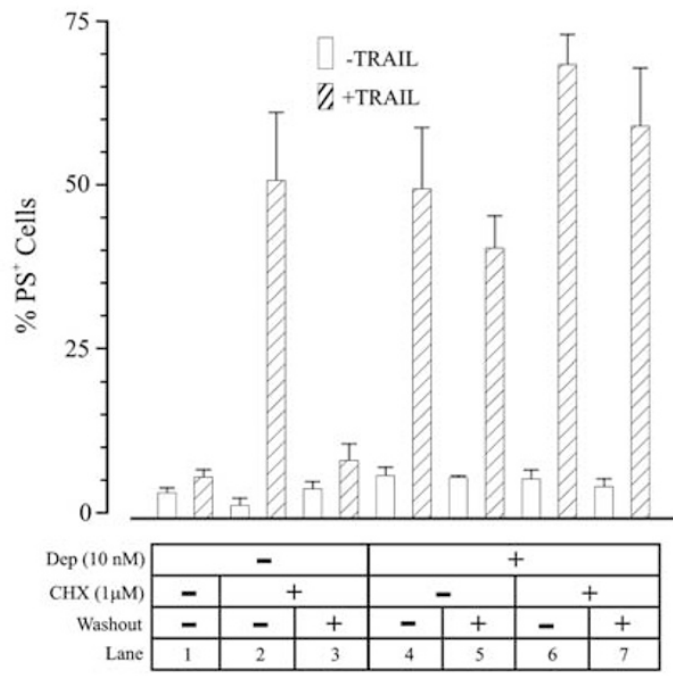

C
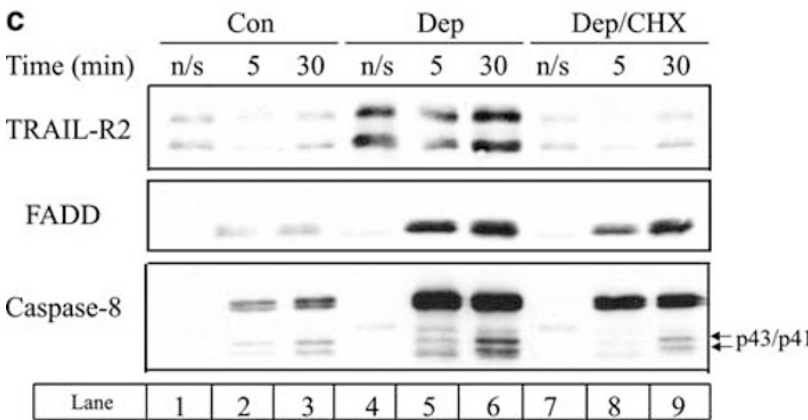

Figure 8 Depsipeptide-mediated facilitation of DISC formation occurs in the presence of $\mathrm{CHX}$ and in the absence of upregulation of TRAIL-R2. (a) U937 cells were incubated for $8 \mathrm{~h}$ either alone (Control) or in the presence of depsipeptide $(10 \mathrm{nM})$ in the presence or absence of $\mathrm{CHX}(5 \mu \mathrm{M})$. Cells were then exposed to biotinylated TRAIL $(500 \mathrm{ng} / \mathrm{ml})$ for the indicated times and a DISC isolated as described in Materials and methods. To provide an unstimulated receptor control, biotinylated TRAIL was added to lysate from untreated cells (u/s). The DISCs obtained were analyzed by Western blotting. (b) K562 cells were treated for $12 \mathrm{~h}$ in the presence or absence of depsipeptide $(10 \mathrm{nM})$ with or without $\mathrm{CHX}(1 \mu \mathrm{M})$ and then washed, where indicated, to remove the chemicals. Cells were then cultured for a further $4 \mathrm{~h}$ in the presence or absence of TRAIL $(100 \mathrm{ng} / \mathrm{ml})$ and apoptosis assessed by externalization of PS. (c) K562 cells were incubated either alone or with depsipeptide (Dep) $(10 \mathrm{nM})$ for the indicated times in the presence or absence of CHX and the DISC was then isolated and analyzed as described above for U937 cells

TRAIL-induced apoptosis even when incubated in the presence of $\mathrm{CHX}$ and following wash-out (Figure $8 \mathrm{~b}$, lanes 6 and 7). Thus, the sensitization of TRAIL-induced apoptosis by depsipeptide occurred in a similar manner in both K562 and
U937 cells. We then investigated the effects of the $\mathrm{CHX}$ treatment on DISC formation in $\mathrm{K} 562$ cells. Treatment with depsipeptide again resulted in increased DISC formation with increased TRAIL-R2, FADD and caspase-8 within the DISC compared to control cells (Figure 8c, compare lanes 5 and 6 with lanes 2 and 3 ). Treatment with depsipeptide in the presence of $\mathrm{CHX}$ completely inhibited the depsipeptideinduced increase in TRAIL-R2 within the DISC such that the amount of TRAIL-R2 in the DISC appeared identical to control cells (Figure $8 \mathrm{c}$ ). However, even in the absence of any increase in TRAIL-R2 in the DISC, an increase in FADD and caspase-8 within the native TRAIL DISC was still observed (Figure $8 \mathrm{c}$, compare lanes 8 and 9 with lanes 2 and 3). The depsipeptideinduced increase in FADD and caspase-8 recruitment to the TRAIL DISC was decreased by the pretreatment with $\mathrm{CHX}$ (Figure 8c, compare lanes 5 and 6 with lanes 8 and 9). Taken together, these results demonstrate conclusively that the facilitated DISC formation in the presence of depsipeptide can still occur in the absence of upregulation of TRAIL-R2.

\section{Discussion}

CLL, one of the most common hematological malignancies in the western world, is characterized by the accumulation of mature nonproliferating $B$ cells resulting from a failure of cells to undergo apoptosis rather than by excessive cellular proliferation. ${ }^{50}$ The disease is incurable with current chemotherapeutic strategies. New chemotherapeutic agents are required in CLL to overcome resistance of cells to commonly used agents. Signalling of apoptosis via cell surface receptors, such as TRAIL receptors, is an attractive therapeutic target for this and other malignancies, but many reports have demonstrated the resistance of primary malignant $B$ cells to death receptor-induced apoptosis. ${ }^{17-21,37,51}$

The most striking finding of the present study was the dramatic sensitization of CLL cells to TRAIL-induced apoptosis following pretreatment with HDAC inhibitors. The potentiation of TRAIL-induced apoptosis by conventional chemotherapeutic agents and irradiation has been described, but these treatments are inherently toxic, whereas HDAC inhibitors are relatively nontoxic. ${ }^{24,25}$ HDAC inhibitors potentiated TRAIL-induced apoptosis in CLL as well as other resistant cells by activating the extrinsic pathway with caspase- 8 as the apical caspase. Activation of the extrinsic pathway may be particularly valuable as an additional approach to the treatment of CLL, as it should bypass many of the normal resistance mechanisms employed by cells against the intrinsic pathway. Support for this was provided by our findings of the efficacy of the TRAIL/HDAC inhibitor combination both in CLL cells that express high levels of $\mathrm{Bcl}-2$ and in Bcl-XL-overexpressing Jurkat cells (Figure 1), which are resistant to many chemical agents that activate the intrinsic pathway.

How do HDAC inhibitors sensitize CLL cells to TRAILinduced apoptosis? A number of recent reports principally in cell lines rather than in primary cells such as those used in this study have also described the potentiation of TRAIL-induced apoptosis by different HDAC inhibitors. ${ }^{34,52,53}$ One of these studies reports a synergistic interaction of TRAIL and HDAC 
inhibitors when both agents were cotreated for 24 or $48 \mathrm{~h}$, but not when cells were pretreated with HDAC inhibitors. ${ }^{53}$ In their study, the enhanced apoptosis did not involve an alteration in FLIP or in modification of death receptor expression, but was caspase dependent and associated with enhanced loss of both mitochondrial membrane potential and mitochondrial cytochrome $c$, suggesting that the synergism occurred primarily by the intrinsic pathway. However, a role for the extrinsic pathway was also demonstrated using cell lines stably expressing CrmA, or dominant-negative caspase-8 or FADD. ${ }^{53}$ While the present manuscript was in preparation, a report appeared showing that cotreatment with the HDAC inhibitor LAQ824, a cinnamic acid hydroxamate, enhanced TRAIL-induced apoptosis by increasing DISC activity. ${ }^{52}$ In contrast to our findings, LAQ824 decreased the levels of some antiapoptotic molecules, including Bcl-2, XIAP and c-FLIP $P_{L}$, but in agreement with our study induced marked death receptor expression. ${ }^{52}$ In the same study, the authors also showed an increased formation of a native TRAIL DISC with increased recruitment of FADD and caspase-8 in SKW 6.4 B lymphoblast cells. Thus, in our study and that of Guo et al., ${ }^{52}$ the primary mechanism of sensitization occurs upstream of mitochondria at the level of DISC formation. In addition, we have also shown that pretreatment with the HDAC inhibitor facilitates enhanced formation of a TRAIL DISC accompanied by an increased recruitment of FADD and caspase-8. This presumably leads to a more active DISC and therefore greater activation of caspase-8 and subsequent cell death (Figure 4). Thus, based on our data and other data in the literature, the most likely mechanism whereby HDAC inhibitors sensitize cells to TRAIL appears to be due to an increased DISC formation. Although initially we thought that this increased sensitization to TRAIL-induced apoptosis involved an early upregulation of TRAIL-R2, the studies with CHX in CLL, U937 and $\mathrm{K} 562$ cells clearly demonstrate that this upregulation is not required for HDAC inhibitor-induced sensitization (Figures 7 and 8). Thus, the HDAC inhibitor-induced sensitization to TRAIL-induced apoptosis did not appear to be due to de novo protein synthesis of a new proapoptotic protein, but rather may be due to effects of HDAC inhibitors on acetylation of nonhistone targets, such as $\mathrm{Hsp} 90$ and Ku70. ${ }^{54,55}$ However, as yet, we cannot rule out that other mechanisms also contribute to the HDAC inhibitor potentiation of TRAILinduced apoptosis. One such possibility is that HDAC inhibitors lead to an increased lateral diffusion of TRAIL-R2 molecules, so facilitating their aggregation and formation of the DISC, as has been reported for CD95. ${ }^{56}$ As internalized CD95 is directed to the endosomal pathway, ${ }^{57}$ it is possible that enhanced endocytosis and receptor recycling could also contribute to the increased TRAIL DISC formation. Some differences between the CD95 and TRAIL DISCs in CLL cells are also apparent, based on our finding that HDAC inhibitors potentiate TRAIL-, but not CD95-induced, apoptosis. This difference was not due to the use of agonistic CD95 antibodies and TRAIL ligand, as CLL cells were still resistant to CD95 ligand-induced apoptosis (data not shown). Although the reasons for these differences are unclear, it is possible that the CD95 DISC is not active in CLL cells, or alternatively that the HDAC inhibitors in some way specifically modify the TRAIL DISC in CLL cells. Our finding that HDAC inhibitors potentiate both TRAIL- and CD95-induced apoptosis in Jurkat cells (Figure 1c) provided some support for this suggestion. The observation that similar levels of $C-F_{L} P_{L}$ were recruited to the DISC and cleaved to an $\sim$ p43 fragment in cells treated with TRAIL alone or pretreated with depsipeptide (Figure 4a) did not support a critical role for decreases in C-FLIP $\mathrm{L}_{\mathrm{L}}$ being responsible for the marked sensitization of CLL cells to TRAIL. Similarly, a recent study also demonstrated that a decrease in $C-F_{L} P_{L}$ alone was insufficient to sensitize CLL cells to TRAIL. ${ }^{58}$

Although the primary action of HDAC inhibitors on the sensitization of CLL cells to TRAIL is due to facilitated DISC formation, they may exert a secondary effect by also potentiating TRAIL-induced apoptosis at the mitochondrial level. The increased levels of the proapoptotic BH3-onlyprotein $\mathrm{Bim}_{\mathrm{EL}}$ may mediate some of this potentiation. ${ }^{49,59}$ The increased levels of $\mathrm{Bim}_{\mathrm{EL}}$ may be due to either increased protein synthesis or decreased proteasomal degradation. ${ }^{60}$ This additional effect of HDAC inhibitors may make them particularly effective in potentiating TRAIL-induced apoptosis, as in many cells TRAIL-induced apoptosis also involves a mitochondrial amplification component. ${ }^{47,48,61}$ it is also possible that the upregulation of Bim may be involved in the induction of apoptosis by many different HDAC inhibitors in many diverse cellular systems.

As most commonly used agents induce apoptosis in CLL and other malignancies by perturbation of mitochondria and activation of the intrinsic pathway, our finding of a novel strategy that activates the extrinsic pathway may be particularly valuable as it could circumvent many of the resistance mechanisms of the intrinsic pathway. As the combination of TRAIL and an HDAC inhibitor caused no significant toxicity in normal $B$ and $T$ cells, it raises the possibility that it may be of value in the treatment of CLL as well as other incurable malignancies.

\section{Materials and Methods}

\section{Lymphocyte purification, cell lines and culture}

Blood samples were obtained from CLL patients, staged according to the Binet system, during routine diagnosis at the Leicester Royal Infirmary with patient consent and local ethical committee approval. Samples were collected into Li-Heparin tubes. CLL cells were purified as described previously ${ }^{20}$ and resuspended in RPMl 1640 medium $\left(4 \times 10^{6}\right.$ cells $\left./ \mathrm{ml}\right)$ at $37^{\circ} \mathrm{C}$ in an atmosphere of $5 \% \mathrm{CO}_{2}$ and incubated as indicated with TRAIL $(100 \mathrm{ng} / \mathrm{ml})$ or anti-CD95 $(100 \mathrm{ng} / \mathrm{ml})$. Where indicated, CLL and other cells were incubated with depsipeptide $(10 \mathrm{nM})$ or Trichostatin $\mathrm{A}(0.25 \mu \mathrm{M})$ for 8-16 h prior to treatment with TRAIL for a further $0-8 \mathrm{~h}$. Blood samples from healthy donors were obtained by consent and peripheral blood mononuclear cells purified as described for CLL cells. ${ }^{20} \mathrm{~B}$ cells were then further enriched by depletion of T, NK, dendritic and erythroid cells, monocytes and granulocytes, by MACS ${ }^{\mathbb{R}}$ separation using a human B Cell Isolation Kit II (Miltenyi Biotec, Surrey, UK). B-cell purity, assessed by measuring $\mathrm{CD}_{19}{ }^{+}$cells using FACS analysis, was increased from $16 \pm 3$ to $48 \pm 4 \%$ (mean \pm S.E.M., $n=7$ ). The residual fraction was primarily T cells. Both normal $B$ and T cells $\left(\approx 0.5 \times 10^{6} \mathrm{cell} / \mathrm{s} / \mathrm{ml}\right)$ were cultured and treated in the same way as CLL cells. Jurkat T cells (clone E6-1) obtained from ECACC (Wiltshire, UK) or CLL cells were pretreated for $1 \mathrm{~h}$ with the caspase inhibitor, benzyloxycarbonyl-Val-Ala-Asp (OMe) fluoromethyl 
ketone (Z-VAD.fmk) (Enzyme Systems, CA, USA). Wild-type, caspase-8deficient and $\mathrm{Bcl}-\mathrm{XL}$ stably transfected Jurkat cells were cultured as described. ${ }^{62,63}$ U937 cells were obtained from ECACC and cultured in RPMI medium containing $10 \%$ FBS and $5 \%$ Glutamax $^{\mathrm{TM}}$. Dr. S Chow, MRC Toxicology Unit, kindly provided K562 cells. Samples were either analyzed for apoptosis or pelleted and stored at $-80^{\circ} \mathrm{C}$ for subsequent Western blotting.

\section{Materials}

Media and serum were from Life Technologies, Inc. (Paisley, UK). Human recombinant TRAIL was prepared as described previously. ${ }^{64}$ TRAIL-R1R4 antibodies (clones M271, M413, M430 and M444, respectively) were kind gifts from Immunex Corp., Seattle, WA, USA. ${ }^{65}$ Anti-CD95 monoclonal antibody ( $\mathrm{CH}-11$ clone) was from Upstate Biotechnology Inc. (Lake Placid, NY, USA). Depsipeptide was kindly provided by Dr. E Sausville (NCI, USA) and Trichostatin A was from Sigma (Poole, UK). M-791, a specific caspase-3 inhibitor, ${ }^{39}$ and c-FLIP antibodies ${ }^{66}$ were kindly provided by Dr. D Nicholson (Merck Frosst, Canada) and Dr. P Krammer (German Cancer Centre, Heidelberg), respectively. A third c-FLIP antibody raised to residues $447-464$ of $c-F L I P L$ was obtained from Upstate Biotechnology (Milton Keynes, UK). Caspase antibodies were from sources described previously. ${ }^{62} \mathrm{~A}$ monoclonal antibody against $\mathrm{Bcl}-2$ was from Santa Cruz Biotechnology (Santa Cruz, CA, USA). Anti-Bax Clone 3, FADD and XIAP antibodies were from Transduction Laboratories (Lexington, KY, USA). The Mcl-1 antibody was from Santa Cruz (Santa Cruz, CA, USA) and the c-IAP1 and 2 antibodies were from R\&D Systems (Abingdon, UK). A rabbit polyclonal antibody to the C-terminus of TRAILR2 for Western blot analysis was obtained from Alexis Corp. (Nottingham, UK). The anti-Bim antibody was from Calbiochem (La Jolla, CA, USA). Bisindolylmaleimide IX, a protein kinase $C$ inhibitor known to induce apoptosis in CLL cells, ${ }^{67}$ was from Alexis Biochemicals (Nottingham, UK). Other reagents were from Sigma (Poole, UK).

\section{Quantification of apoptosis and Western blot analysis}

Apoptosis was quantified by PS externalization or loss of mitochondrial membrane potential $\left(\psi_{\mathrm{m}}\right)$ in the presence of propidium iodide as described previously. ${ }^{20,68}$ Samples for Western blot analysis were prepared and caspases detected as described previously. ${ }^{68}$ Histones were extracted as described previously. ${ }^{27}$ Acetylated $\mathrm{H} 3(\mathrm{~K} 9 / 14)$ and acetylated $\mathrm{H} 4$ (K5/8/ 12/16) were detected by Western blot analysis using polyclonal rabbit antibodies (Cat \# 06-599 and \# 06-598, respectively) from Upstate Biotechnology.

\section{Assessment of cell surface receptor expression}

Purified CLL and Jurkat cells were resuspended in blocking buffer $(10 \%$ normal goat serum in PBS) and incubated for 30 min on ice to block nonspecific binding, then incubated with anti-TRAIL receptor antibodies (diluted 1:50), anti-CD95 antibody (clone $\mathrm{CH}-11)(50 \mathrm{ng} / \mathrm{ml})$ or an isotypematched control antibody for $1 \mathrm{~h}$ on ice and then analyzed by flow cytometry as described previously. ${ }^{20}$

\section{DISC analysis}

DISC precipitation was performed using biotin-tagged recombinant TRAIL (biotinylated TRAIL) essentially as described previously. ${ }^{20,46}$ CLL cells $\left(2.5 \times 10^{8}\right.$ cells per treatment) were either cultured alone or with depsipeptide $(10 \mathrm{nM})$ for either 8 or $16 \mathrm{~h}$ and then treated with biotinylated TRAIL ( $500 \mathrm{ng} / \mathrm{ml}$ ) for 5,15 or $30 \mathrm{~min}$ and DISC formation determined. ${ }^{20,46}$ Western blotting was performed using $30 \mu \mathrm{l}$ of eluted complexes from streptavidin-agarose beads representing DISC precipitated from $3 \times 10^{7}$ cells. U937, K562 or Jurkat cells $\left(1 \times 10^{8}\right.$ cells per treatment) were similarly exposed to depsipeptide followed by biotinylated TRAIL and then DISC formation was assessed.

\section{Measurement of TRAIL-R2 in U937 and CLL cells}

U937 $\left(1 \times 10^{7}\right.$ cells per treatment) and CLL $\left(3 \times 10^{7}\right.$ cells per treatment $)$ cells were treated with or without depsipeptide $(10 \mathrm{nM})$ and $\mathrm{CHX}(2.5-$ $5 \mu \mathrm{M}$ ) for $8 \mathrm{~h}$ (U937 cells) or 8-16 h (CLL cells). After this treatment, cells were then washed three times with ice-cold phosphate-buffered saline, lysed for $30 \mathrm{~min}$ on ice with lysis buffer containing $30 \mathrm{mM}$ Tris- $\mathrm{HCl}(\mathrm{pH} 8)$, $150 \mathrm{mM} \mathrm{NaCl}, 10 \%$ glycerol, $1 \%$ Triton X-100 supplemented with Complete $^{\mathrm{TM}}$ protease inhibitors (Roche Applied Science). Lysates were then cleared by centrifugation at $16000 \times g$ for $30 \mathrm{~min}$ at $4^{\circ} \mathrm{C}$. Biotinylated-TRAIL ( $1 \mu \mathrm{g}$ per treatment) was added to the lysate and complexes were precipitated overnight at $4^{\circ} \mathrm{C}$ using streptavidinSepharose ${ }^{\mathrm{TM}}$ beads (Amersham Biosciences). The beads were washed six times with ice-cold lysis buffer and analyzed by Western blotting using anti-TRAIL-R2 antibody.

\section{Statistical analysis}

One-way ANOVA was used employing Tukey's post hoc comparison between means with a significance of $P<0.05$ throughout.

\section{Acknowledgements}

We thank Roger Snowden for flow cytometric analysis and technical assistance and Dr. M Mulheran for help with statistical analysis. This work was supported by the Medical Research Council. Jurkat $T$ cells either deficient in caspase-8 or stably expressing Bcl-XL were kindly provided by Dr. J Blenis (Massachusetts General Hospital, Boston, MA) or Dr. Schulze-Osthoff (Freiburg, Germany), respectively.

\section{References}

1. Bratton SB, MacFarlane M, Cain K and Cohen GM (2000) Protein complexes activate distinct caspase cascades in death receptor and stress-induced apoptosis. Exp. Cell. Res. 256: 27-33

2. Reed JC (2000) Mechanisms of apoptosis. Am. J. Pathol. 157: 1415-1430

3. Chinnaiyan AM, O'Rourke K, Tewari M and Dixit VM (1995) FADD, a novel death domain-containing protein, interacts with the death domain of Fas and initiates apoptosis. Cell 81: 505-512

4. Kischkel FC, Hellbardt S, Behrmann I, Germer M, Pawlita M, Krammer PH and Peter ME (1995) Cytotoxicity-dependent APO-1 (Fas/CD95)-associated proteins form a death-inducing signaling complex (DISC) with the receptor. EMBO J. 14: 5579-5588

5. Bodmer JL, Holler N, Reynard S, Vinciguerra P, Schneider P, Juo P, Blenis J and Tschopp J (2000) TRAIL receptor-2 signals apoptosis through FADD and caspase-8. Nat. Cell. Biol. 2: 241-243

6. Kischkel FC, Lawrence DA, Chuntharapai A, Schow P, Kim KJ and Ashkenazi A (2000) Apo2L/TRAIL-dependent recruitment of endogenous FADD and caspase-8 to death receptors 4 and 5 . Immunity 12: 611-620

7. Sprick MR, Weigand MA, Rieser E, Rauch CT, Juo P, Blenis J, Krammer PH and Walczak H (2000) FADD/MORT1 and caspase-8 are recruited to TRAIL 
receptors 1 and 2 and are essential for apoptosis mediated by TRAIL receptor 2. Immunity 12: 599-609

8. Boldin MP, Goncharov TM, Goltsev YV and Wallach D (1996) Involvement of $\mathrm{MACH}$, a novel MORT1/FADD-interacting protease, in Fas/APO-1- and TNF receptor-induced cell death. Cell 85: 803-815

9. Muzio M, Chinnaiyan AM, Kischkel FC, O'Rourke K, Shevchenko A, Ni J Scaffidi C, Bretz JD, Zhang M, Gentz R, Mann M, Krammer PH, Peter ME and Dixit VM (1996) FLICE, a novel FADD-homologous ICE/CED-3-like protease, is recruited to the CD95 (Fas/APO-1) death-inducing signaling complex. Cell 85: 817-827

10. Marsters SA, Sheridan JP, Donahue CJ, Pitti RM, Gray CL, Goddard AD, Bauer KD and Ashkenazi A (1996) Apo-3, a new member of the tumor necrosis factor receptor family, contains a death domain and activates apoptosis and NFkappa B. Curr. Biol. 6: 1669-1676

11. Wiley SR, Schooley K, Smolak PJ, Din WS, Huang CP, Nicholl JK, Sutherland GR, Smith TD, Rauch C, Smith CA and Goodwin RG (1995) Identification and characterization of a new member of the TNF family that induces apoptosis. Immunity 3: 673-682

12. Walczak H, Miller RE, Ariail K, Gliniak B, Griffith TS, Kubin M, Chin W, Jones J, Woodward A, Le T, Smith C, Smolak P, Goodwin RG, Rauch CT, Schuh JC and Lynch DH (1999) Tumoricidal activity of tumor necrosis factor-related apoptosis-inducing ligand in vivo. Nat. Med. 5: 157-163

13. Ashkenazi A and Dixit VM (1998) Death receptors: signaling and modulation. Science 281: 1305-1308

14. Irmler M, Thome M, Hahne M, Schneider P, Hofmann K, Steiner V, Bodmer JL, Schroter M, Burns K, Mattmann C, Rimoldi D, French LE and Tschopp J (1997) Inhibition of death receptor signals by cellular FLIP. Nature 388: 190-195

15. Scaffidi C, Schmitz I, Krammer PH and Peter ME (1999) The role of c-FLIP in modulation of CD95-induced apoptosis. J. Biol. Chem. 274: 1541-1548

16. Krueger A, Schmitz I, Baumann S, Krammer PH and Kirchhoff S (2001) Cellular FLICE-inhibitory protein splice variants inhibit different steps of caspase-8 activation at the CD95 death-inducing signaling complex. J. Biol. Chem. 276: 20633-20640

17. Plumas J, Jacob MC, Chaperot L, Molens JP, Sotto JJ and Bensa JC (1998) Tumor B cells from non-Hodgkin's lymphoma are resistant to CD95 (Fas/ Apo-1)-mediated apoptosis. Blood 91: 2875-2885

18. Xerri L, Devilard E, Hassoun J, Haddad P and Birg F (1997) Malignant and reactive cells from human lymphomas frequently express Fas ligand but display a different sensitivity to Fas-mediated apoptosis. Leukemia 11: 1868-1877

19. Xerri L, Bouabdallah R, Devilard E, Hassoun J, Stoppa AM and Birg F (1998) Sensitivity to Fas-mediated apoptosis is null or weak in B-cell non-Hodgkin's lymphomas and is moderately increased by CD40 ligation. Br. J. Cancer 78 225-232

20. MacFarlane M, Harper N, Snowden RT, Dyer MJ, Barnett GA, Pringle JH and Cohen GM (2002) Mechanisms of resistance to TRAIL-induced apoptosis in primary B cell chronic lymphocytic leukaemia. Oncogene 21: 6809-6818

21. Wang D, Freeman GJ, Levine H, Ritz J and Robertson MJ (1997) Role of the CD40 and CD95 (APO-1/Fas) antigens in the apoptosis of human B-cell malignancies. Br. J. Haematol. 97: 409-417

22. Ozoren N and El-Deiry WS (2003) Cell surface death receptor signaling in normal and cancer cells. Semin. Cancer Biol. 13: 135-147

23. Wajant $H$, Pfizenmaier $K$ and Scheurich $P$ (2002) TNF-related apoptosis inducing ligand (TRAIL) and its receptors in tumor surveillance and cancer therapy. Apoptosis 7: 449-459

24. Johnstone RW (2002) Histone-deacetylase inhibitors: novel drugs for the treatment of cancer. Nat. Rev. Drug Discov. 1: 287-299

25. Marks P, Rifkind RA, Richon VM, Breslow R, Miller T and Kelly WK (2001) Histone deacetylases and cancer: causes and therapies. Nat. Rev. Cancer 1: 194-202

26. Melnick A and Licht JD (2002) Histone deacetylases as therapeutic targets in hematologic malignancies. Curr. Opin. Hematol. 9: 322-332

27. Aron JL, Parthun MR, Marcucci G, Kitada S, Mone AP, Davis ME, Shen T, Murphy T, Wickham J, Kanakry C, Lucas DM, Reed JC, Grever MR and Byrd JC (2003) Depsipeptide (FR901228) induces histone acetylation and inhibition of histone deacetylase in chronic lymphocytic leukemia cells concurrent with activation of caspase 8-mediated apoptosis and down-regulation of c-FLIP protein. Blood 102: 652-658

28. Henderson C, Mizzau M, Paroni G, Maestro R, Schneider C and Brancolini C (2003) Role of caspases, Bid, and p53 in the apoptotic response triggered by histone deacetylase inhibitors trichostatin- $A$ (TSA) and suberoylanilide hydroxamic acid (SAHA). J. Biol. Chem. 278: 12579-12589

29. Kwon SH, Ahn SH, Kim YK, Bae GU, Yoon JW, Hong S, Lee HY, Lee YW, Lee HW and Han JW (2002) Apicidin, a histone deacetylase inhibitor, induces apoptosis and Fas/Fas ligand expression in human acute promyelocytic leukemia cells. J. Biol. Chem. 277: 2073-2080

30. Ruefli AA, Ausserlechner MJ, Bernhard D, Sutton VR, Tainton KM, Kofler R, Smyth MJ and Johnstone RW (2001) The histone deacetylase inhibitor and chemotherapeutic agent suberoylanilide hydroxamic acid (SAHA) induces a cell-death pathway characterized by cleavage of Bid and production of reactive oxygen species. Proc. Natl. Acad. Sci. USA 98: 10833-10838

31. Bernhard D, Skvortsov S, Tinhofer I, Hubl H, Greil R, Csordas A and Kofler R (2001) Inhibition of histone deacetylase activity enhances Fas receptormediated apoptosis in leukemic lymphoblasts. Cell Death Differ. 8: 1014-1021

32. Glick RD, Swendeman SL, Coffey DC, Rifkind RA, Marks PA, Richon VM and La Quaglia MP (1999) Hybrid polar histone deacetylase inhibitor induces apoptosis and CD95/CD95 ligand expression in human neuroblastoma. Cancer Res. 59: 4392-4399

33. Mitsiades N, Mitsiades CS, Richardson PG, McMullan C, Poulaki V, Fanourakis G, Schlossman R, Chauhan D, Munshi NC, Hideshima T, Richon VM, Marks PA and Anderson KC (2003) Molecular sequelae of histone deacetylase inhibition in human malignant B cells. Blood 101: 4055-4062

34. Neuzil J, Swettenham E and Gellert N (2004) Sensitization of mesothelioma to TRAIL apoptosis by inhibition of histone deacetylase: role of Bcl-xL downregulation. Biochem. Biophys. Res. Commun. 314: 186-191

35. Hernandez A, Thomas R, Smith F, Sandberg J, Kim S, Chung DH and Evers BM (2001) Butyrate sensitizes human colon cancer cells to TRAIL-mediated apoptosis. Surgery 130: 265-272

36. Inoue H, Shiraki K, Ohmori S, Sakai T, Deguchi M, Yamanaka T, Okano H and Nakano T (2002) Histone deacetylase inhibitors sensitize human colonic adenocarcinoma cell lines to TNF-related apoptosis inducing ligand-mediated apoptosis. Int. J. Mol. Med. 9: 521-525

37. Snell V, Clodi K, Zhao S, Goodwin R, Thomas EK, Morris SW, Kadin ME, Cabanillas F, Andreeff M and Younes A (1997) Activity of TNF-related apoptosis-inducing ligand (TRAIL) in haematological malignancies. Br. J. Haematol. 99: 618-624

38. Byrd JC, Shinn C, Ravi R, Willis CR, Waselenko JK, Flinn IW, Dawson NA and Grever MR (1999) Depsipeptide (FR901228): a novel therapeutic agent with selective, in vitro activity against human B-cell chronic lymphocytic leukemia cells. Blood 94: 1401-1408

39. Hotchkiss RS, Chang KC, Swanson PE, Tinsley KW, Hui JJ, Klender P, Xanthoudakis S, Roy S, Black C, Grimm E, Aspiotis R, Han Y, Nicholson DW and Karl IE (2000) Caspase inhibitors improve survival in sepsis: a critical role of the lymphocyte. Nat. Immunol. 1: 496-501

40. Srinivasula SM, Ahmad M, Fernandes-Alnemri T and Alnemri ES (1998) Autoactivation of procaspase- 9 by Apaf-1-mediated oligomerization. Mol. Cell 1: 949-957

41. MacFarlane M, Cohen GM and Dickens M (2000) JNK (c-Jun N-terminal kinase) and p38 activation in receptor-mediated and chemically-induced apoptosis of T-cells: differential requirements for caspase activation. Biochem. J. 348 (Part 1): 93-101

42. Srinivasula SM, Ahmad M, Fernandes-Alnemri T, Litwack $G$ and Alnemri ES (1996) Molecular ordering of the Fas-apoptotic pathway: the Fas/APO-1 protease Mch5 is a CrmA-inhibitable protease that activates multiple Ced-3/ ICE-like cysteine proteases. Proc. Natl. Acad. Sci. USA 93: 14486-14491

43. Bonavida B, Ng CP, Jazirehi A, Schiller G and Mizutani Y (1999) Selectivity of TRAIL-mediated apoptosis of cancer cells and synergy with drugs: the trail to non-toxic cancer therapeutics (review). Int. J. Oncol. 15: 793-802

44. Fulda S and Debatin KM (2003) Death receptor signaling in cancer therapy. Curr. Med. Chem. Anti-Cancer Agents 3: 253-262

45. Krueger A, Baumann S, Krammer PH and Kirchhoff S (2001) FLICE-inhibitory proteins: regulators of death receptor-mediated apoptosis. Mol. Cell. Biol. 21: 8247-8254

46. Harper N, Farrow SN, Kaptein A, Cohen GM and MacFarlane M (2001) Modulation of tumor necrosis factor apoptosis-inducing ligand-induced NF-kappa B activation by inhibition of apical caspases. J. Biol. Chem. 276: 34743-34752

47. LeBlanc H, Lawrence D, Varfolomeev E, Totpal K, Morlan J, Schow P, Fong S, Schwall R, Sinicropi D and Ashkenazi A (2002) Tumor-cell resistance to death 
receptor-induced apoptosis through mutational inactivation of the proapoptotic Bcl-2 homolog Bax. Nat. Med. 8: 274-281

48. Deng $Y$, Lin $Y$ and $W u X$ (2002) TRAlL-induced apoptosis requires Bax-dependent mitochondrial release of Smac/DIABLO. Genes Dev. 16: 33-45

49. O'Reilly LA, Cullen L, Visvader J, Lindeman GJ, Print C, Bath ML, Huang DC and Strasser A (2000) The proapoptotic BH3-only protein bim is expressed in hematopoietic, epithelial, neuronal, and germ cells. Am. J. Pathol. 157: 449-461

50. Reed JC (1998) Molecular biology of chronic lymphocytic leukemia. Semin. Oncol. 25: 11-18

51. Panayiotidis $P$, Ganeshaguru K, Foroni L and Hoffbrand AV (1995) Expression and function of the FAS antigen in B chronic lymphocytic leukemia and hairy cell leukemia. Leukemia 9: 1227-1232

52. Guo F, Sigua C, Tao J, Bali P, George P, Li Y, Wittmann S, Moscinski L, Atadja $P$ and Bhalla K (2004) Cotreatment with histone deacetylase inhibitor LAQ824 enhances Apo-2L/tumor necrosis factor-related apoptosis inducing ligandinduced death inducing signaling complex activity and apoptosis of human acute leukemia cells. Cancer Res. 64: 2580-2589

53. Rosato RR, Almenara JA, Dai Y and Grant S (2003) Simultaneous activation of the intrinsic and extrinsic pathways by histone deacetylase (HDAC) inhibitors and tumor necrosis factor-related apoptosis-inducing ligand (TRAIL) synergistically induces mitochondrial damage and apoptosis in human leukemia cells. Mol. Cancer Ther. 2: 1273-1284

54. Yu X, Guo ZS, Marcu MG, Neckers L, Nguyen DM, Chen GA and Schrump DS (2002) Modulation of p53, ErbB1, ErbB2, and Raf-1 expression in lung cancer cells by depsipeptide FR901228. J. Natl. Cancer Inst. 94: 504-513

55. Cohen HY, Lavu S, Bitterman KJ, Hekking B, Imahiyerobo TA, Miller C, Frye R, Ploegh $\mathrm{H}$, Kessler BM and Sinclair DA (2004) Acetylation of the $C$ terminus of Ku70 by CBP and PCAF controls Bax-mediated apoptosis. Mol. Cell 13: 627-638

56. Varadhachary AS, Edidin M, Hanlon AM, Peter ME, Krammer PH and Salgame $P$ (2001) Phosphatidylinositol $3^{\prime}$-kinase blocks CD95 aggregation and caspase8 cleavage at the death-inducing signaling complex by modulating lateral diffusion of CD95. J. Immunol. 166: 6564-6569

57. Algeciras-Schimnich A, Shen L, Barnhart BC, Murmann AE, Burkhardt JK and Peter ME (2002) Molecular ordering of the initial signaling events of CD95. Mol. Cell. Biol. 22: 207-220

58. Pedersen IM, Kitada S, Schimmer A, Kim Y, Zapata JM, Charboneau L, Rassenti L, Andreeff M, Bennett F, Sporn MB, Liotta LD, Kipps TJ and Reed JC
(2002) The triterpenoid CDDO induces apoptosis in refractory CLL B cells. Blood 100: 2965-2972

59. Bouillet P, Metcalf D, Huang DC, Tarlinton DM, Kay TW, Kontgen F, Adams JM and Strasser A (1999) Proapoptotic Bcl-2 relative Bim required for certain apoptotic responses, leukocyte homeostasis, and to preclude autoimmunity. Science 286: 1735-1738

60. Ley R, Balmanno K, Hadfield K, Weston C and Cook SJ (2003) Activation of the ERK $1 / 2$ signaling pathway promotes phosphorylation and proteasomedependent degradation of the BH3-only protein, Bim. J. Biol. Chem. 278: 18811-18816

61. Ravi R and Bedi A (2002) Requirement of BAX for TRAIL/Apo2L-induced apoptosis of colorectal cancers: synergism with sulindac-mediated inhibition of Bcl-x(L). Cancer Res. 62: 1583-1587

62. Sun XM, Bratton SB, Butterworth M, MacFarlane M and Cohen GM (2002) Bcl2 and $\mathrm{Bcl}-\mathrm{xL}$ inhibit CD95-mediated apoptosis by preventing mitochondrial release of Smac/DIABLO and subsequent inactivation of X-linked inhibitor-ofapoptosis protein. J. Biol. Chem. 277: 11345-11351

63. Harper N, Hughes M, MacFarlane M and Cohen GM (2003) Fas-associated death domain protein and caspase- 8 are not recruited to the tumor necrosis factor receptor 1 signaling complex during tumor necrosis factor-induced apoptosis. J. Biol. Chem. 278: 25534-25541

64. MacFarlane M, Ahmad M, Srinivasula SM, Fernandes-Alnemri T, Cohen GM and Alnemri ES (1997) Identification and molecular cloning of two novel receptors for the cytotoxic ligand TRAIL. J. Biol. Chem. 272: 25417-25420

65. Griffith TS, Rauch CT, Smolak PJ, Waugh JY, Boiani N, Lynch DH, Smith CA, Goodwin RG and Kubin MZ (1999) Functional analysis of TRAIL receptors using monoclonal antibodies. J. Immunol. 162: 2597-2605

66. Rasper DM, Vaillancourt JP, Hadano S, Houtzager VM, Seiden I, Keen SL, Tawa P, Xanthoudakis S, Nasir J, Martindale D, Koop BF, Peterson EP, Thornberry NA, Huang J, MacPherson DP, Black SC, Hornung F, Lenardo MJ, Hayden MR, Roy S and Nicholson DW (1998) Cell death attenuation by 'Usurpin', a mammalian DED-caspase homologue that precludes caspase-8 recruitment and activation by the CD-95 (Fas, APO-1) receptor complex. Cell Death Differ. 5: 271-288

67. Snowden RT, Sun XM, Dyer MJ and Cohen GM (2003) Bisindolylmaleimide IX is a potent inducer of apoptosis in chronic lymphocytic leukaemic cells and activates cleavage of Mcl-1. Leukemia 17: 1981-1989

68. Sun XM, MacFarlane M, Zhuang J, Wolf BB, Green DR and Cohen GM (1999) Distinct caspase cascades are initiated in receptor-mediated and chemicalinduced apoptosis. J. Biol. Chem. 274: 5053-5060 